\title{
Human or Natural Disturbance: Landscape-Scale Dynamics of the Tropical Forests of Puerto Rico
}

\section{Citation}

Foster, D. R., M. Fluet, and E. R. Boose. 1999. “Human or Natural Disturbance: LandscapeScale Dynamics of the Tropical Forests of Puerto Rico." Ecological Applications 9 (2) (May): 555. doi: $10.2307 / 2641144$.

\section{Published Version}

doi:http:10.2307/2641144

\section{Permanent link}

http://nrs.harvard.edu/urn-3:HUL.InstRepos:30677425

\section{Terms of Use}

This article was downloaded from Harvard University's DASH repository, and is made available under the terms and conditions applicable to Other Posted Material, as set forth at http:// nrs.harvard.edu/urn-3:HUL.InstRepos:dash.current.terms-of-use\#LAA

\section{Share Your Story}

The Harvard community has made this article openly available.

Please share how this access benefits you. Submit a story.

\section{Accessibility}




\title{
HUMAN OR NATURAL DISTURBANCE: LANDSCAPE-SCALE DYNAMICS OF THE TROPICAL FORESTS OF PUERTO RICO
}

\author{
D. R. Foster, M. Fluet,' And E. R. Boose \\ Harvard Forest, Harvard University, Petersham, Massachusetts 01366 USA
}

\begin{abstract}
Increasingly, ecologists are recognizing that human disturbance has played an important role in tropical forest history and that many assumptions concerning the relative importance of natural processes warrant re-examination. To assess the historical role of broad-scale human vs. natural disturbance on an intensively studied tropical forest we undertook a landscape-level analysis of forest dynamics in the Luquillo Experimental Forest (LEF; 10871 ha) in eastern Puerto Rico. Using aerial photographs (1936 and 1989), GIS, a model of topographic exposure to hurricane winds, and historical data, we sought to: (1) document historical changes in extent, cover, and type of forest vegetation; (2) evaluate the distribution of land use and hurricane impacts; (3) assess the contributions of these processes in controlling current vegetation patterns; and (4) relate these results to ongoing ecological, conservation, and natural resource discussions.

With $>1000 \mathrm{~m}$ of relief in the LEF, the broad vegetation zones of Tabonuco $(<600 \mathrm{~m}$ above sea level), Colorado (600-900 m), Dwarf ( $>900 \mathrm{~m}$ ), and Palm forest are determined by environmental gradients. However, over the past 60-100 years, forest extent, cover, and type have been transformed: in 1936, $40 \%$ of the LEF was unforested or secondary forest and $<50 \%$ had continuous canopy ( $>80 \%$ cover); in $1989,>97 \%$ was continuous forest. Secondary forest and agricultural lands in 1936 were replaced largely by Tabonuco and Colorado forest, which increased from $8 \%$ and $28 \%$ (1936) to $26 \%$ and $45 \%$ (1989).

These broad-scale vegetation dynamics are best explained by a gradient of human land use, intense at low elevations and decreasing on steep, high terrain, which peaked historically around 1900, followed by a gradual decline in agriculture. GIS analysis and historical sources suggest that essentially all of the LEF was affected by human activity and that Tabonuco forest, which is the focus of LTER research, has been most substantially altered and is largely of secondary origin. Rapid reforestation following agricultural decline has obscured much of the past land use and confirms the resiliency of some tropical forests to intensive human disturbance. Impacts of earlier hurricanes (e.g., in 1928 and 1932), although not evident in the broad forest pattern in 1936, may be significant in explaining the distributions of Colorado and Palm forest. Damage from Hurricane Hugo in 1989 indicates that natural disturbance is increasingly important as land use declines and forest cover and height increase. However, this study and post-Hugo studies emphasize that land use legacies are long-lasting and need to be considered in modern ecological studies and natural resource management. The subtle, although persistent, effects of historical human activities may have profound consequences for modern forest ecosystems in the tropics.
\end{abstract}

Key words: disturbance; Geographic Information Systems; hurricanes; land use; landscape dynamics; Mantel test; modeling; Puerto Rico; succession; topographic exposure; tropical forests.

\section{INTRODUCTION}

Temperate forest ecologists perennially confront the challenge of distinguishing the influence of prior human land use from that of natural disturbance and site conditions in controlling the structure, composition, and dynamics of vegetation (Motzkin et al. 1996, Foster et al. 1998). Most temperate forests have been altered by human activity, and the legacy of these effects controls modern ecosystem characteristics (Williams 1990, Watkins 1993, Whitney 1994). Consequently, the in-

Manuscript received 2 January 1998; revised 15 May 1998; accepted 18 May 1998; final version received 6 July 1998.

1 Present address: RR1, Box 36, Petersham, Massachusetts 01366 USA. terpretation of current forest structure and function and decisions concerning natural resource management and conservation need to incorporate an understanding of land use legacies (Lugo 1994, Foster et al. 1996, Motzkin et al. 1996).

Despite increasing evidence of prehistoric and historical human impacts on tropical forests (e.g., Binford et al. 1987, Roosevelt et al. 1991, Gomez-Pompa and Kaus 1992, Meggars 1992, Northrup and Horn 1996), major questions remain concerning the extent of past land use, the ability of tropical forests to recover from human disturbance, and the relative importance of natural vs. anthropogenic impacts in controlling modern forest structure, function, and dynamics (Gomez-Pompa 1984). Answers to these questions would provide 
essential input into ecological discussions concerning the important processes that structure tropical forest ecosystems, into conservation considerations regarding the dynamics of these systems, and into forest management and environmental concerns regarding their resiliency to such human impacts as logging and deforestation. In the current study, we have employed a combination of historical research, aerial photography, and modeling of topographic exposure to wind to assess the pattern and causes of landscape-scale dynamics in the Luquillo Experimental Forest in Puerto Rico, where good historical documentation exists, but where the established literature strongly asserts that natural processes, such as gap dynamics, hurricane impacts, and landslides, control forest pattern and process.

In Puerto Rico, the largest extent of apparent primary forest (i.e., forest never cleared) occurs in the Luquillo Experimental Forest (LEF) in the eastern half of the island. With its Caribbean location, Puerto Rico experiences frequent, severe hurricanes; much of the interpretation of forest structure, composition, and dynamics in the LEF over the past three decades has focused on natural disturbance by catastrophic wind (Odum 1970, Doyle 1981, Weaver 1986, 1987, Walker et al. 1991, Basnet et al. 1992, Lugo 1992, Waide and Lugo 1992). The remarkably even canopy structure and stem size distribution of the low-elevation $(<600 \mathrm{~m}$ above sea level) Tabonuco forest was interpreted by Odum (1970) as resulting from frequent wind damage, an interpretation recently invoked by Brokaw and Grear (1991). In a comparison of forest composition in the Tabonuco zone with output from FORICO, a FORETstyle model, Doyle (1981) concluded that best agreement was reached when a stochastic disturbance frequency of 11 storms per century was used, assuming a $0-10 \%$ density of tree stems removed each storm (note, however, that this model "fit" does not approximate the historical hurricane regime). The Luquillo Long Term Ecological Reseach (LTER) program was initiated with intensive studies on the Tabonuco forest and an organizing theme of natural disturbance by catastrophic wind, landslides, and gap dynamics (Waide and Lugo 1992). Lugo (1994) recently concluded that nearly 4000 ha of primary forest of all types remains in the LEF.

These interpretations of the extent of intact forest and the pre-eminence of natural processes in controlling forest dynamics contrast markedly with seldomreferenced historical documentation and early studies suggesting that human activity in the LEF during the 19 th and early 20th centuries was extensive well above $700 \mathrm{~m}$ a.s.l. (Hill 1899, Murphy 1916, Wadsworth 1950). Wadsworth (1952) indicated that $<400$ ha of primary Tabonuco forest remained in all of Puerto Rico, White (1963) was able to find relatively undisturbed forest only above $600 \mathrm{~m}$ elevation, and Murphy (1916) stated that forest-cutting occurred throughout all forest areas, resulting in the culling of the valuable large trees. Local studies in sites that include the area studied by Odum (1970) suggest that past human impacts have extensive control over current forest structure, composition, dynamics, and response to disturbance (Scatena 1989, Garcia-Montiel 1991, Zimmerman et al. 1995).

Reconciliation of these divergent interpretations of the causative factors underlying modern patterns and processes is a challenge for Puerto Rican forests, as it is for the entire tropics; it also represents a critical step in the formulation of ecological research programs, forest management policy, and conservation planning. To address the fundamental question of the relative role of human vs. natural disturbance in controlling vegetation patterns, we undertook a broad-scale and historical examination of the entire LEF, using aerial photographs that extend back $60 \mathrm{yr}$, archival and historical records, and our recently developed understanding of wind damage to the LEF landscape (Boose et al. 1994, Foster and Boose 1995). We consider the approaches, methods, and motivations for this study to be broadly applicable to most forested regions, as are the fundamental questions that we posed:

(1) What broad-scale dynamics have occurred in the pattern and extent of forest vegetation; (2) what was the distribution and intensity of past land use activity and hurricane impacts; (3) what are the relative contributions of land use vs. tropical storms to the observed dynamics in vegetation; and (4) how can this information be employed in ongoing ecological, conservation, and natural resource discussions?

The LEF is an ideal location for these studies: (1) USDA Forest Service ownership and long-term studies provide historical documentation of land use and vegetation change; (2) the changing dynamics of land use broadly parallel cultural patterns elsewhere in Puerto Rico and the Caribbean (Thomlinson et al. 1996); (3) strong elevational and physiographic gradients produce spatially varying patterns of vegetation and human activity; and (4) the major vegetation types are readily identified and differentiated on aerial photographs (Wadsworth 1950). Through the LTER program and USDA Forest Service activities, the LEF provides a scientific environment that can incorporate the findings of this study into research and management agendas (Brown et al. 1983, Zimmerman et al. 1995). This research also extends our comparative understanding of human and natural disturbance in temperate and tropical forest ecosystems and the ability of these ecosystems to recover from intensive disturbance (Foster 1993, Boose et al. 1994, Foster et al. 1997).

\section{STUdy AREA}

\section{Vegetation and physical environment}

The LEF occupies 10871 ha in the Luquillo Mountains of northeastern Puerto Rico (Fig. 1). The mountains are largely composed of Cretaceous igneous rocks 

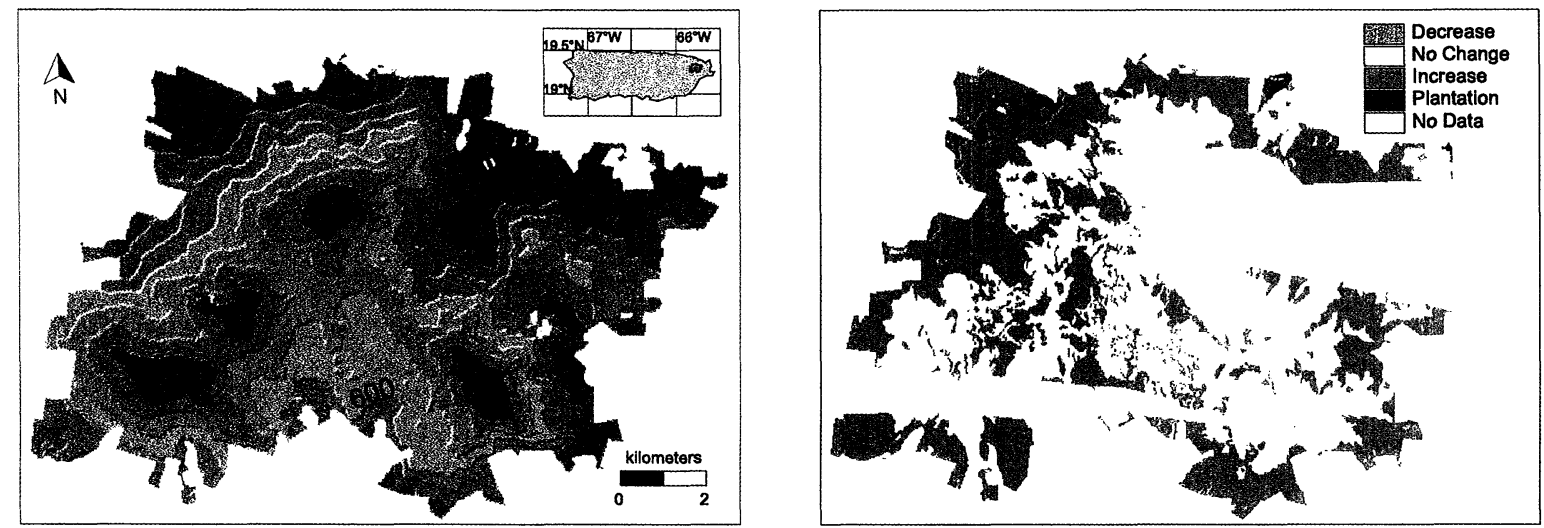

Fig. 1. Left: map of the Luquillo Experimental Forest in Puerto Rico depicting elevation ranging from $50 \mathrm{~m}$ above sea level (a.s.l.) (green) to $>1050 \mathrm{~m}$ a.s.l. (red), the LEF border, and the general location in eastern Puerto Rico (inset). Right: Geographical patterns of change in forest cover in the Luquillo Experimental Forest between 1936 and 1989 for the area (7462 ha) covered by both sets of aerial photographs.

with intrusive Tertiary material. Soils tend to be leached acid clays that are nutrient poor and prone to waterlogging. Elevations range from $<100$ to $1075 \mathrm{~m}$ a.s.l., and the climate is characterized by a mean annual precipitation of $320 \mathrm{~cm}$ and a mean temperature of $21^{\circ} \mathrm{C}$. A strong gradient of increasing precipitation with elevation exerts a controlling influence on the biota (Snyder et al. 1987). Four major vegetation typesTabonuco, Colorado, Dwarf, and Palm forest-are physiognomically distinct and tend to occupy different physiographic positions (Wadsworth 1949). Tabonuco forest, which predominates below $600 \mathrm{~m}$ a.s.l., is dominated by tabonuco (Dacryodes excelsa) and is characterized by tall $(25-30 \mathrm{~m})$ trees, low light intensity at ground level, and high species richness (170 tree species). Colorado forest occupies middle elevations (600-900 $\mathrm{m}$ a.s.l.), where the tendency toward saturated soils leads to shallow-rooted and shorter stature trees and low species richness ( $\sim 50$ tree species). Prominent trees include palo colorado (Cyrilla racemiflora), caimitillo (Micropholis garciniaefolia, M. chrysophylloides), and laurel sabino (Magnolia splendens). Dwarf forest ( $>900 \mathrm{~m}$ a.s.l.) on upper montane ridges consists of short $(<10 \mathrm{~m})$ vegetation characterized by abundant epiphytes, slow growth, and only 19 tree species on water-saturated soils. Palm forest occurs discontinuously across the elevational ranges of Colorado and Tabonuco forests. Prestoea montana, the dominant species, is most abundant at higher elevations, but is important along drainages and streams to low elevations.

The natural disturbance regime is incompletely understood and includes hurricanes, landslides, and gap dynamics (Scatena 1989, Waide and Lugo 1992, Foster and Boose 1995, Larsen and Parks 1997). Over 70 hurricanes have occurred since 1700 (Salivia 1972), with severe storms this century in 1916, 1928, 1932, 1956, 1989, and 1998 (E. Boose, unpublished data). Hurricane Hugo in 1989 damaged broad areas (Walker et al.
1992, Boose et al. 1994). Landslides exert intensive local damage, strongly related to slope, geological substrate, and human activity (Guariguata and Larsen 1989).

\section{History of the Luquillo Experimental Forest}

Archaeological information suggests that the indigenous population of Puerto Rico exerted minor impact on interior montane regions (Wadsworth 1950). Spanish land use in the LEF was slight until the 19th century, when government land distribution led to agriculture, forest cutting, and mining (Hill 1899, Wadsworth 1950, Scatena 1989, Garcia-Montiel and Scatena 1994). By the late 19th century, pasture covered $>55 \%$ of Puerto Rico as forest clearance and agriculture reached a peak (Garcia-Montiel 1991). Spanish Crown Lands in the Luquillo Mountains (5012 ha) were designated as a forest reserve in 1898 and were ceded to the United States to become the Luquillo Forest Preserve (USFS 1985). During early U.S. ownership, management concentrated on timber production through reforestation, although timber and agricultural trespass was considerable (Wadsworth 1950); however, with the 1931 extension of the Weeks Law Authority to Puerto Rico, the U.S. government began to purchase $>6200$ ha of adjoining lands and to eliminate private activity. The 20th century decline in the agricultural economy of Puerto Rico, coupled with migration to industrialized San Juan and the United States resulted in a rural population decline, broad-scale agricultural abandonment, and natural reforestation (Birdsey and Weaver 1982).

\section{Methods}

\section{Historical data}

Primary sources of information on the history of land use and vegetation change in the LEF include the archives and publications of the USDA Forest Service. 
From the 1890 s through the 1930 s, timber resources were assessed across the Luquillo Forest Reserve in general field studies (Hill 1899, Gifford 1905, Murphy 1916, Holdridge 1939; USFS, unpublished archives). For the exterior half of the LEF that surrounds these original Spanish crown lands, detailed parcel inventories from 1930 to 1940 include: maps of vegetation and land use; inventories of wood resources, agricultural land and buildings; descriptions of site history, condition, and accessibility; and soil classifications (USFS, unpublished archives). For the interior Crown lands that were ceded directly from Spain to the United States, data before 1950 are primarily descriptive. Since the time of U.S. ownership, vegetation surveys, timber inventories, and research reports provide fairly detailed information on forest conditions and human activity (Brown et al. 1983, Weaver 1987). In the LTER program, research and data concentrate on the Tabonuco forest (Waide and Lugo 1992), with recent interest in the entire landscape (McDowell et al. 1992, Boose et al. 1994, Foster and Boose 1995).

\section{Aerial photograph interpretation}

The major vegetation types in the LEF (Tabonuco, Colorado, Dwarf, Palm) are readily distinguished on aerial photographs and are separated from reforesting secondary lands or open lands on the basis of canopy height, structure, and texture (Wadsworth 1950, Boose et al. 1994). In this study, vegetation maps were interpreted from aerial photographs taken in 1936 (black and white; 1:15000 scale; 10 871-ha coverage) and 1989 (color; 1:20000 scale; 7462-ha cloud-free coverage) using a mirror stereoscope, transferred to U.S. Geological Survey topographic maps (1:24 000) using a zoom-transfer scope, and digitized on a Geographic Information System (GIS). On the photographs, homogeneous polygons (minimum size 0.1 ha) were delineated on the basis of canopy signature, and were classified into 42 classes based on a combination of forest type (Unforested [ $<20 \%$ tree cover], Secondary, Tabonuco, Colorado, Dwarf, Palm, Plantation) and percent forest cover $(0-10 \%, 10-20 \%, 20-50 \%, 50-80 \%$, and $80-100 \%)$. Identification of the 1989 vegetation types was verified through extensive ground truthing, comparison with modern reference areas, and consultation with local ecologists (F. Scatena, D. Garcia-Montiel, A. Lugo, J. Thomlinson, R. Waide, and J. Zimmerman, personal communication). The 1936 maps were verified against 1930s acquisition maps, inventories, and contemporary studies of the LEF (Bates 1930, Garcia 1936, Holdridge 1939, Marrero 1947; USFS, unpublished data).

Due to persistent cloud cover at higher elevations in the LEF, most photography and remote-sensing imagery for the area are incomplete (W. Lawrence, personal communication). The 1936 photographs are unusual in the completeness of cover, absence of clouds, and high resolution. For 1989, complete, high-resolution pho- tographs exist for $70 \%$ of the LEF. Consequently, results in this study are presented for the entire 1936 coverage (10 $871 \mathrm{ha}$ ), the 1989 coverage (7462 ha), and the 1936 area coincident with the 1989 area (7462 ha). All estimates of change from 1936 to 1989 are analyzed from the coincident coverage.

\section{GIS development and analysis}

The 1936 and 1989 vegetation maps were georeferenced, digitized, and transferred into IDRISI, a rasterbased GIS (Eastman 1993). Analyses were undertaken at a grid cell resolution of $30 \mathrm{~m}$. Separate forest cover and forest type maps were derived from the original vegetation maps. An overlay for slope (degrees) was derived from the digital elevation model (DEM; 5-m contour) and an overlay for nearest distance to the LEF border (meters) was derived from an overlay of the LEF border (USFS, unpublished data). IDRISI was also used to measure forest patch sizes, to cross-tabulate the 1936 and 1989 forest cover and forest type maps, and to analyze output from the topographic exposure model.

\section{Hurricane modeling and analysis}

The 1936 photographs were examined for expected signs of hurricane damage from the severe storms in 1928 and 1932 (E. Boose, unpublished data), but no clear evidence was discernible. Few notes on wind damage were found in the 1930s acquisition surveys (USFS, unpublished data). Consequently, possible wind effects on forest structure and composition in 1936 were investigated by modeling landscape-level exposure to hurricane winds with the EXPOS model (Boose et al. 1994) and comparing the results to the 1936 forest cover and forest type maps. The EXPOS model classifies each point on a DEM as protected from or exposed to a given wind direction, depending on whether or not the point falls within the wind shadow cast by points upwind. The wind shadow is estimated by assuming that the wind bends downward no more than a fixed inflection angle from the horizontal as it passes over a height of land (Boose et al. 1994). The EXPOS model was used to create maps of predicted topographic exposure in $5^{\circ}$ protection classes (i.e., fully exposed, protected for an inflection angle of $0^{\circ}$ but exposed for an inflection angle of $5^{\circ}$, protected at $5^{\circ}$ but exposed at $10^{\circ}$, etc.) for eight wind directions ( $\mathrm{N}$, NE, E, SE, S, SW, W, NW).

\section{Statistical analysis}

The 1936 and 1989 forest cover and forest type maps were analyzed for correlation with elevation, slope, and distance from the LEF border. The 1936 maps were also analyzed for correlation with predicted topographic exposure to hurricane winds. We expected that each of these factors might influence forest cover and forest type, as follows: (1) elevation controls environmental conditions (e.g., temperature and moisture) and, there- 

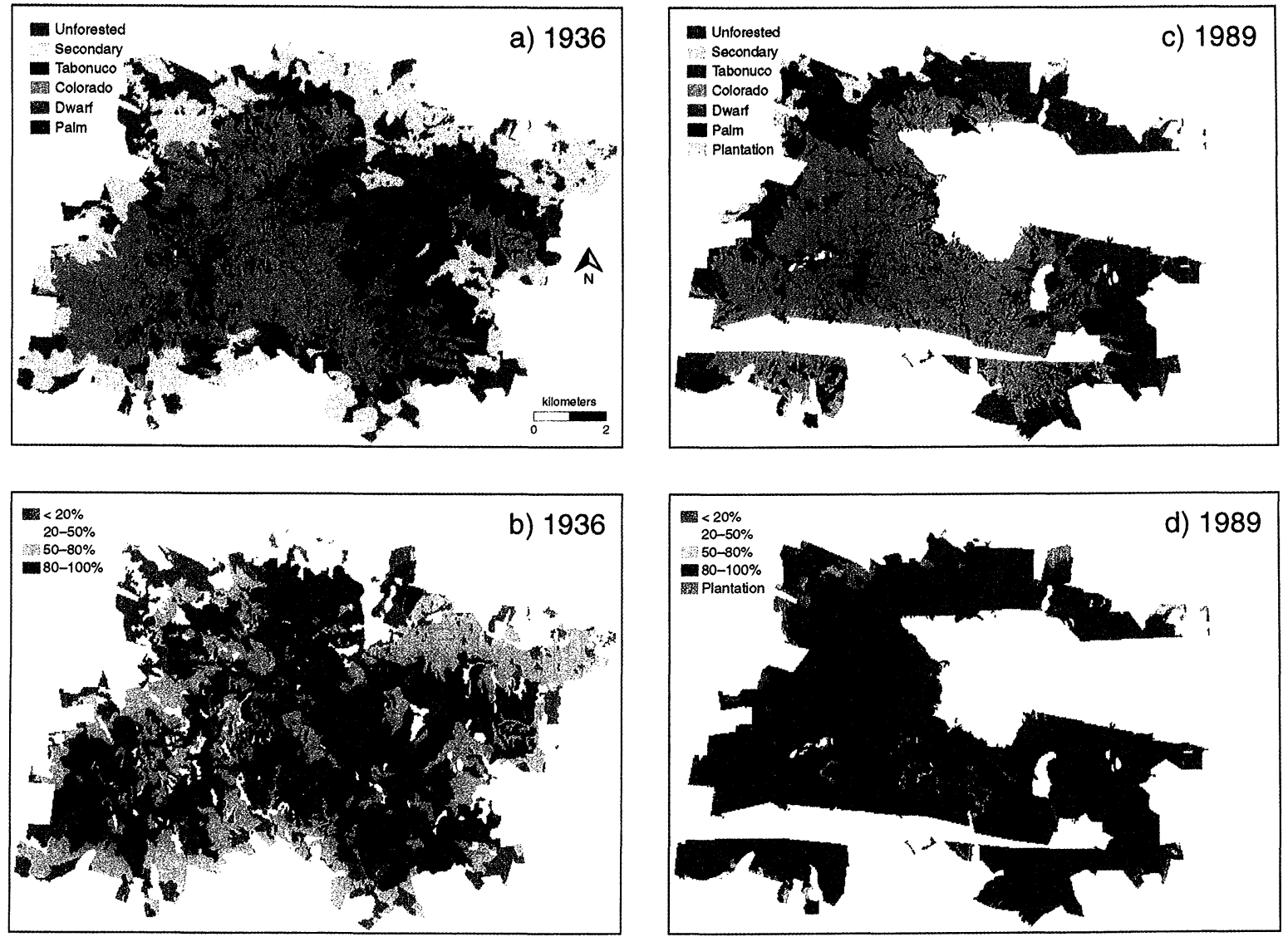

Fig. 2. Maps of the Luquillo Experimental Forest in Puerto Rico showing the major forest types (a, c) and percent forest cover (b, d) in 1936 and 1989. Cloud cover eliminated photographic coverage for portions of the 1989 maps, and some very small gaps, e.g., in the northeastern corner at low elevation, represent private inholdings. Major trends include substantial natural regrowth of Tabonuco and Colorado forest on areas previously in agriculture or secondary scrub vegetation.

TABLE 1. Extent of forest cover and forest type categories in the Luquillo Experimental Forest in 1936 and 1989, calculated as a percentage of the area analyzed in the available aerial photograph coverage. For 1936, values are given for the entire study area and for the subregion that is coincident with the area analyzed in 1989.

\begin{tabular}{lccc}
\hline \hline & \multicolumn{3}{c}{ Percentage of area } \\
\cline { 2 - 4 } & \multicolumn{3}{c}{1936} \\
Category & $\begin{array}{c}1936 \text { entire } \\
(10,871 \text { ha })\end{array}$ & $\begin{array}{c}1989 \\
\text { coincident }\end{array}$ & $\begin{array}{c}\text { coincident } \\
(7462 \text { ha })\end{array}$ \\
\hline Forest cover & & & \\
520\% & 11.5 & 13.1 & 1.2 \\
$20-50 \%$ & 11.9 & 13.0 & 0.3 \\
$50-80 \%$ & 27.2 & 26.6 & 1.2 \\
80-100\% & 49.3 & 47.3 & 95.6 \\
Plantation & & & 1.7 \\
Forest type & & & \\
Unforested & 11.5 & 13.1 & 1.2 \\
Secondary & 22.8 & 25.8 & 1.6 \\
Tabonuco & 8.1 & 2.8 & 26.1 \\
Colorado & 28.2 & 31.0 & 44.7 \\
Dwarf & 1.4 & 1.1 & 1.4 \\
Palm & 27.9 & 26.2 & 23.4 \\
Plantation & & & 1.7 \\
\hline
\end{tabular}

fore, land use; (2) slope controls environmental conditions (e.g., soil conditions) and land use; (3) distance from the LEF border controls land use (through the history of land ownership, regulation, and access); and (4) topographic exposure controls damage from hurricane winds. We expected that the impacts of land use and hurricane damage would differ significantly between 1936 and 1989.

In most cases, the dependent variables (forest cover and forest type) and the predictor variables (elevation, slope, distance, and exposure) were spatially autocorrelated. Therefore, we tested for correlations using the Mantel test (Mantel 1967, Manly 1997a), which performs a regression on distance matrices and can treat space (i.e., geographic location) explicitly as a predictor variable. Both simple Mantel coefficients (e.g., forest cover vs. elevation) and partial Mantel coefficients (e.g., forest cover vs. elevation controlling for slope, distance, and space) were calculated; the latter make it possible to rank the relative contributions of various factors. Note that the simple Mantel coefficient of a variable vs. space is a measure of the spatial autocorrelation of that variable; i.e., a positive value indicates 
TABLE 2. Patch characteristics of forest cover and forest type maps in the Luquillo Experimental Forest in 1936 and 1989. Calculations are based on $30-\mathrm{m}$ grid cells.

\begin{tabular}{|c|c|c|c|}
\hline $\begin{array}{c}\text { Patch } \\
\text { characteristics }\end{array}$ & $\begin{array}{c}1936 \\
\text { entire }\end{array}$ & $\begin{array}{c}1936 \\
\text { coin- } \\
\text { cident }\end{array}$ & $\begin{array}{l}1989 \\
\text { coin- } \\
\text { cident }\end{array}$ \\
\hline \multicolumn{4}{|c|}{ Forest cover map (all categories) } \\
\hline Number of patches & 473 & 437 & 242 \\
\hline Minimum patch size (ha) & 0.1 & 0.1 & 0.1 \\
\hline Maximum patch size (ha) & 4972.7 & 2630.1 & 6587.2 \\
\hline Median patch size (ha) & 2.0 & 1.5 & 0.5 \\
\hline Mean patch size (ha) & 23.0 & 17.2 & 31.1 \\
\hline 1 SD patch size (ha) & 232.4 & 130.1 & 423.5 \\
\hline \multicolumn{4}{|c|}{ Forest type map (all categories) } \\
\hline Number of patches & 516 & 513 & 621 \\
\hline Minimum patch size (ha) & 0.1 & 0.1 & 0.1 \\
\hline Maximum patch size (ha) & 1626.4 & 1274.0 & 2598.0 \\
\hline Median patch size (ha) & 1.7 & 1.4 & 0.9 \\
\hline Mean patch size (ha) & 21.1 & 14.7 & 12.1 \\
\hline 1 SD patch size (ha) & 111.8 & 79.0 & 110.1 \\
\hline
\end{tabular}

that points close together in space tend to have similar values, while a negative value indicates that points close together in space tend to have dissimilar values.

Forest cover was analyzed using maps of average percent canopy cover. Forest types were analyzed individually using presence/absence maps for each forest type ( 0 , absent; 1 , present). Changes in vegetation from 1936 to 1989 were analyzed using difference maps (i.e., 1989 map minus 1936 map). Maps were sampled using a stratified random selection of points in IDRISI. The Mantel analysis of 1936 vegetation was based on 247 points selected from the entire 1936 study area, whereas the analysis of 1989 vegetation and 1936 to 1989 vegetation change was based on 246 points from the coincident study area. Mantel coefficients and significance levels were calculated using Manly's RT soft- ware (Manly 1997b), with 1000 randomizations for each test.

\section{RESULTS}

\section{Vegetation in 1936}

In 1936, much of the LEF was deforested or reforesting naturally following widespread forest clearance, agriculture, and timber harvest (Fig. 2). Less than half of the area was continuous forest ( $>80 \%$ forest cover; Table 1). Nearly $12 \%$ was Unforested and $\sim 23 \%$ was Secondary forest recovering from human activity. Within forested areas, Palm (28\%) and Colorado forest (28\%) were most abundant, with lesser amounts of Tabonuco $(8 \%)$ and Dwarf $(1 \%)$ forest. No plantations were evident. The distributions of patch sizes for both forest cover and forest type were highly skewed, with a predominance of small patches (Table 2). Forest cover increased with elevation and distance from the LEF border (Table 3). Unforested and Secondary forest areas were located at lower elevations near the LEF border; Tabonuco was concentrated in the northeast part of the LEF at lower elevations; and Colorado, Dwarf, and Palm were found at higher elevations in the interior of the LEF, with Palm tending to occur on steeper slopes (Tables 4, 5).

The Mantel analysis showed positive spatial autocorrelation for forest cover and some forest types (Unforested, Secondary) and negative spatial autocorrelation for Palm (Table 6). The distributions of forest cover and most forest types (Secondary, Tabonuco, Colorado, Dwarf) were best explained by elevation, whereas the distribution of Palm was best explained by distance from the LEF border. The distribution of Unforested areas was most strongly correlated with space, indicating a spatial structure to the data not explained by elevation, slope, or distance.

TABLE 3. Forest cover distribution in the Luquillo Experimental Forest, showing mean elevation, slope, and distance to the LEF border for each forest cover category in 1936 and 1989. Calculations are based on 30-m grid cells.

\begin{tabular}{|c|c|c|c|c|c|c|}
\hline \multirow{2}{*}{$\begin{array}{l}\text { Forest cover } \\
\text { category }\end{array}$} & \multicolumn{2}{|c|}{1936 entire } & \multicolumn{2}{|c|}{1936 coincident } & \multicolumn{2}{|c|}{1989 coincident } \\
\hline & Mean & $1 \mathrm{SD}$ & Mean & $1 \mathrm{SD}$ & Mean & $1 \mathrm{SD}$ \\
\hline \multicolumn{7}{|l|}{ Elevation (m) } \\
\hline$\leq 20 \%$ & 417 & 177 & 407 & 180 & 397 & 216 \\
\hline $20-50 \%$ & 440 & 193 & 436 & 196 & 497 & 156 \\
\hline $50-80 \%$ & 544 & 202 & 582 & 193 & 483 & 254 \\
\hline $80-100 \%$ & 673 & 165 & 677 & 155 & 594 & 199 \\
\hline Plantation & & & & & 298 & 67 \\
\hline \multicolumn{7}{|l|}{ Slope $\left({ }^{\circ}\right)$} \\
\hline$\leq 20 \%$ & 12.6 & 6.7 & 12.5 & 6.4 & 11.9 & 7.2 \\
\hline $20-50 \%$ & 14.6 & 6.9 & 14.2 & 6.7 & 12.3 & 6.9 \\
\hline $50-80 \%$ & 15.2 & 7.4 & 15.0 & 7.4 & 12.3 & 7.5 \\
\hline $80-100 \%$ & 14.9 & 7.6 & 14.5 & 7.6 & 14.4 & 7.3 \\
\hline Plantation & & & & & 11.3 & 4.9 \\
\hline \multicolumn{7}{|l|}{ Distance $(\mathrm{m})$} \\
\hline$\leq 20 \%$ & 484 & 640 & 420 & 564 & 417 & 626 \\
\hline $20-50 \%$ & 678 & 741 & 599 & 690 & 585 & 785 \\
\hline $50-80 \%$ & 1027 & 875 & 1038 & 883 & 852 & 958 \\
\hline $80-100 \%$ & 1660 & 907 & 1500 & 829 & 1149 & 894 \\
\hline Plantation & & & & & 199 & 154 \\
\hline
\end{tabular}


TABLE 4. Forest type distribution in the Luquillo Experiment Forest, showing mean elevation, slope, and distance to the LEF border for each forest type category in 1936 and 1989. Calculations are based on 30-m grid cells.

\begin{tabular}{|c|c|c|c|c|c|c|}
\hline \multirow{2}{*}{$\begin{array}{l}\text { Measure and } \\
\text { forest type } \\
\text { category }\end{array}$} & \multicolumn{2}{|c|}{1936 entire } & \multicolumn{2}{|c|}{1936 coincident } & \multicolumn{2}{|c|}{1989 coincident } \\
\hline & Mean & $1 \mathrm{SD}$ & Mean & $1 \mathrm{SD}$ & Mean & $1 \mathrm{SD}$ \\
\hline \multicolumn{7}{|l|}{ Elevation (m) } \\
\hline Unforested & 417 & 177 & 407 & 180 & 397 & 216 \\
\hline Secondary & 408 & 159 & 417 & 156 & 328 & 174 \\
\hline Tabonuco & 415 & 91 & 441 & 121 & 376 & 131 \\
\hline Colorado & 729 & 107 & 725 & 98 & 701 & 113 \\
\hline Dwarf & 959 & 38 & 955 & 28 & 955 & 29 \\
\hline Palm & 668 & 155 & 675 & 151 & 622 & 182 \\
\hline Plantation & & & & & 298 & 67 \\
\hline \multicolumn{7}{|l|}{ Slope $\left({ }^{\circ}\right)$} \\
\hline Unforested & 12.6 & 6.7 & 12.5 & 6.4 & 11.9 & 7.2 \\
\hline Secondary & 15.0 & 6.9 & 15.0 & 6.8 & 11.8 & 6.6 \\
\hline Tabonuco & 15.0 & 6.4 & 15.4 & 7.0 & 15.5 & 7.2 \\
\hline Colorado & 12.5 & 6.7 & 12.0 & 6.5 & 13.0 & 6.8 \\
\hline Dwarf & 15.0 & 9.1 & 12.3 & 8.0 & 13.9 & 7.7 \\
\hline Palm & 17.5 & 7.9 & 17.3 & 8.0 & 16.0 & 8.1 \\
\hline Plantation & & & & & 11.3 & 4.9 \\
\hline \multicolumn{7}{|l|}{ Distance $(\mathrm{m})$} \\
\hline Unforested & 484 & 640 & 420 & 564 & 417 & 626 \\
\hline Secondary & 462 & 443 & 420 & 352 & 112 & 97 \\
\hline Tabonuco & 1556 & 987 & 1502 & 1176 & 528 & 504 \\
\hline Colorado & 1574 & 826 & 1546 & 769 & 1471 & 849 \\
\hline Dwarf & 1856 & 741 & 2221 & 585 & 2277 & 543 \\
\hline Palm & 1712 & 941 & 1565 & 853 & 1205 & 935 \\
\hline Plantation & & & & & 199 & 154 \\
\hline
\end{tabular}

TABLE 5. Distribution of forest types in the Luquillo Experimental Forest in 1936 (entire study area) by elevation, slope, and distance from the LEF border.

\begin{tabular}{|c|c|c|c|c|c|c|}
\hline \multirow[b]{2}{*}{$\begin{array}{c}\text { Variable } \\
\text { and category }\end{array}$} & \multicolumn{6}{|c|}{ Percentage of distribution } \\
\hline & $\begin{array}{l}\text { Unforested } \\
\text { (1255 ha) }\end{array}$ & $\begin{array}{l}\text { Secondary } \\
(2484 \text { ha) }\end{array}$ & $\begin{array}{l}\text { Tabonuco } \\
(877 \mathrm{ha})\end{array}$ & $\begin{array}{l}\text { Colorado } \\
\text { (3066 ha) }\end{array}$ & $\begin{array}{c}\text { Dwarf } \\
\text { (156 ha) }\end{array}$ & $\begin{array}{c}\text { Palm } \\
\text { (3034 ha) }\end{array}$ \\
\hline \multicolumn{7}{|l|}{ Elevation $(\mathrm{m})$} \\
\hline$<100$ & & $<1$ & & & & \\
\hline $100-199$ & 9 & 9 & $<1$ & & & \\
\hline $200-299$ & 20 & 19 & 11 & & & $<1$ \\
\hline $300-399$ & 20 & 20 & 31 & & & 4 \\
\hline $400-499$ & 18 & 22 & 39 & 1 & & 11 \\
\hline $500-599$ & 19 & 16 & 17 & 10 & & 18 \\
\hline $600-699$ & 7 & 10 & 2 & 30 & & 24 \\
\hline $700-799$ & 3 & 3 & $<1$ & 33 & & 21 \\
\hline $800-899$ & 3 & 1 & & 20 & 6 & 15 \\
\hline $900-999$ & 1 & & & 6 & 78 & 7 \\
\hline$\geq 1000$ & & & & 1 & 16 & $<1$ \\
\hline \multicolumn{7}{|l|}{ Slope $\left({ }^{\circ}\right)$} \\
\hline$<5$ & 14 & 8 & 8 & 15 & 15 & 7 \\
\hline $5-9$ & 24 & 16 & 14 & 22 & 16 & 11 \\
\hline $10-14$ & 36 & 36 & 34 & 37 & 28 & 28 \\
\hline $15-19$ & 14 & 19 & 23 & 13 & 13 & 20 \\
\hline $20-24$ & 8 & 13 & 15 & 8 & 11 & 18 \\
\hline $25-29$ & 3 & 6 & 5 & 3 & 10 & 10 \\
\hline $30-34$ & 1 & 2 & 1 & 1 & 6 & 5 \\
\hline $35-39$ & $<1$ & $<1$ & $<1$ & $<1$ & $<1$ & 2 \\
\hline $40-44$ & $<1$ & $<1$ & & & $<1$ & $<1$ \\
\hline$\geq 45$ & & & & & & $<1$ \\
\hline \multicolumn{7}{|l|}{ Distance (m) } \\
\hline$<500$ & 72 & 67 & 14 & 7 & 2 & 11 \\
\hline $500-999$ & 16 & 22 & 22 & 22 & 9 & 17 \\
\hline $1000-1499$ & 3 & 7 & 20 & 22 & 26 & 17 \\
\hline $1500-1999$ & 3 & 1 & 16 & 20 & 25 & 16 \\
\hline $2000-2499$ & 3 & 2 & 6 & 13 & 17 & 17 \\
\hline $2500-2999$ & 2 & $<1$ & 10 & 9 & 11 & 12 \\
\hline $3000-3499$ & $<1$ & & 10 & 5 & 9 & 7 \\
\hline$\geq 3500$ & $<1$ & & 3 & 1 & 1 & 4 \\
\hline
\end{tabular}


TABLE 6. Correlation of 1936 forest cover and forest type in the Luquillo Experimental Forest (entire study area) with elevation, slope, distance to the LEF border, and space, where $r$ is the Mantel coefficient and $P$ is the significance after 1000 randomizations.

\begin{tabular}{|c|c|c|c|c|c|c|c|c|}
\hline \multirow[b]{2}{*}{ Variable } & \multicolumn{2}{|c|}{ Elevation } & \multicolumn{2}{|c|}{ Slope } & \multicolumn{2}{|c|}{ Distance } & \multicolumn{2}{|c|}{ Space } \\
\hline & $r$ & $P$ & $r$ & $P$ & $r$ & $P$ & $r$ & $P$ \\
\hline Space & 0.207 & 0.001 & NS & & -0.026 & 0.054 & & \\
\hline Cover $\dagger$ & 0.238 & 0.001 & NS & & 0.173 & 0.001 & 0.128 & 0.001 \\
\hline Cover Space $\ddagger$ & 0.203 & 0.001 & NS & & 0.180 & 0.001 & & \\
\hline Cover | Envir. $\S$ & 0.171 & 0.001 & NS & & 0.149 & 0.001 & 0.096 & 0.001 \\
\hline Unforested & 0.168 & 0.002 & NS & & NS & & 0.159 & 0.001 \\
\hline Unforested Space & 0.112 & 0.023 & NS & & NS & & & \\
\hline Unforested | Envir. & 0.103 & 0.041 & NS & & NS & & 0.138 & 0.001 \\
\hline Secondary & 0.296 & 0.001 & NS & & 0.090 & 0.011 & 0.181 & 0.001 \\
\hline Secondary 1 Space & 0.242 & 0.001 & NS & & 0.099 & 0.006 & & \\
\hline Secondary | Envir. & 0.231 & 0.001 & NS & & 0.057 & 0.070 & 0.135 & 0.001 \\
\hline Tabonuco & NS & & NS & & NS & & NS & \\
\hline Tabonuco | Space & 0.097 & 0.054 & NS & & NS & & & \\
\hline Tabonuco | Envir. & 0.088 & 0.094 & NS & & NS & & -0.066 & 0.059 \\
\hline Colorado & 0.154 & 0.001 & NS & & NS & & NS & \\
\hline Colorado I Space & 0.171 & 0.001 & NS & & NS & & & \\
\hline Colorado | Envir. & 0.174 & 0.001 & NS & & NS & & -0.042 & 0.013 \\
\hline Dwarf & 0.247 & 0.001 & NS & & 0.121 & & NS & \\
\hline Dwarf | Space & 0.297 & 0.001 & NS & & 0.118 & 0.038 & & \\
\hline Dwarf | Envir. & 0.279 & 0.001 & NS & & NS & 0.039 & -0.115 & 0.006 \\
\hline Palm & NS & & 0.082 & 0.017 & 0.126 & 0.001 & -0.062 & 0.001 \\
\hline Palm Space & NS & & 0.081 & 0.017 & 0.124 & 0.001 & & \\
\hline Palm | Envir. & NS & & 0.082 & 0.016 & 0.120 & 0.001 & -0.062 & 0.002 \\
\hline
\end{tabular}

Note: NS indicates values of $r$ that are not significant $(P>0.1)$.

$\dagger$ Cover is the forest cover (all forest types).

\# Space indicates a partial correlation controlling for space.

$\S \mid$ Envir. indicates a partial correlation controlling for the other three dependent variables.

An upper bound for the extent of primary forest (i.e., forest never cleared) in the LEF was estimated from the 1936 forest cover and forest type maps by isolating areas that had high forest cover $(80-100 \%)$ but were not Secondary forest. Results showed a maximum limit of 5060 ha of primary forest, including 380 ha of Tabonuco, 2350 ha of Colorado, 135 ha of Dwarf, and 2195 ha of Palm forest.

\section{Vegetation in 1989}

The extent of continuous forest and the abundance of major forest types are strikingly different in 1989 than in 1936 (Table 1, Fig. 2). In 1989, $96 \%$ of the LEF in the aerial photograph (7462 ha) is continuous forest ( $>80 \%$ cover). Within this forested area, Colorado occupies $45 \%$, Tabonuco $26 \%$, Palm 23\%, and Plantations nearly $2 \%$. The distributions of patch sizes for both forest cover and forest type were more skewed in 1989 than in 1936, with an increase in mean and maximum patch size, but a decrease in median size (Table 2). As the extent of forest increased through reforestation of the low-elevation, marginal areas of the LEF, the average distance from the LEF border declined for all forest cover and forest type categories except Dwarf forest, whereas average slope and elevation decreased for nearly all forest cover categories and average elevation decreased for all forest types (Tables 3,4). Small patches of Unforested land in the
Colorado zone at high elevations in the interior of the LEF are enigmatic (Fig. 2); some were created by landslides; however, some appear to have been deliberately cleared. Plantations lay largely within $500 \mathrm{~m}$ of the border and below $400 \mathrm{~m}$ a.s.l. (Table 7).

The Mantel analysis showed positive spatial autocorrelation for forest cover and most forest types (Unforested, Secondary, Tabonuco, Colorado; Table 8). The distributions of most forest types (Secondary, Tabonuco, Colorado, Dwarf, Plantation) were best explained by elevation, whereas the distribution of Palm was best explained by slope and distance from the LEF border. The distributions of forest cover and Unforested areas were correlated only with space, indicating a spatial structure to the data not explained by elevation, slope, or distance (note that forest cover was almost entirely uniform at $80-100 \%$ ).

\section{Forest change from 1936 to 1989}

Major changes occurred over the 50-yr period in the amount, type, geographical distribution, and spatial pattern of forest cover. Structurally, the most pronounced change was conversion of Unforested, Secondary, and open-canopy areas to dense forest (Fig. 2). Forest cover increased particularly at lower elevations, near the margins of the LEF, and within major valleys, resulting in a broad-scale redistribution of forest cover and forest type categories (Fig. 1). Ridgetops cleared 
TABLE 7. Distribution of forest types in the Luquillo Experimental Forest in 1989 by elevation, slope, and distance from the LEF boundary.

\begin{tabular}{|c|c|c|c|c|c|c|c|}
\hline \multirow[b]{2}{*}{$\begin{array}{c}\text { Variable } \\
\text { and category }\end{array}$} & \multicolumn{7}{|c|}{ Percentage of distribution } \\
\hline & $\begin{array}{l}\text { Unforested } \\
\text { (89 ha) }\end{array}$ & $\begin{array}{l}\text { Secondary } \\
\text { (118 ha) }\end{array}$ & $\begin{array}{l}\text { Tabonuco } \\
(1950 \text { ha) }\end{array}$ & $\begin{array}{l}\text { Colorado } \\
\text { (3333 ha) }\end{array}$ & $\begin{array}{c}\text { Dwarf } \\
(106 \text { ha) }\end{array}$ & $\begin{array}{c}\text { Palm } \\
(1744 \text { ha })\end{array}$ & $\begin{array}{c}\text { Plantation } \\
\text { (123 ha) }\end{array}$ \\
\hline \multicolumn{8}{|l|}{ Elevation (m) } \\
\hline$<100$ & 2 & 2 & & & & & \\
\hline $100-199$ & 18 & 33 & 10 & & & 3 & 9 \\
\hline $200-299$ & 21 & 13 & 21 & & & 3 & 34 \\
\hline $300-399$ & 10 & 8 & 23 & $<1$ & & 5 & 51 \\
\hline $400-499$ & 16 & 21 & 28 & 3 & & 15 & 6 \\
\hline $500-599$ & 13 & 23 & 15 & 14 & & 16 & \\
\hline $600-699$ & 10 & $<1$ & 3 & 33 & & 21 & \\
\hline $700-799$ & 7 & 2 & 1 & 30 & & 19 & \\
\hline $800-899$ & 1 & & & 15 & 14 & 14 & \\
\hline $900-999$ & 2 & & & 5 & 90 & 4 & \\
\hline$\geq 1000$ & $<1$ & & & $<1$ & 6 & $<1$ & \\
\hline \multicolumn{8}{|l|}{ Slope $\left({ }^{\circ}\right)$} \\
\hline$<5$ & 21 & 16 & 7 & 13 & 15 & 9 & 12 \\
\hline $5-9$ & 23 & 31 & 15 & 21 & 15 & 15 & 25 \\
\hline $10-14$ & 30 & 30 & 36 & 36 & 33 & 30 & 49 \\
\hline $15-19$ & 13 & 13 & 18 & 15 & 17 & 18 & 11 \\
\hline $20-24$ & 7 & 6 & 13 & 10 & 11 & 15 & 3 \\
\hline $25-29$ & 4 & 3 & 7 & 3 & 5 & 9 & $<1$ \\
\hline $30-34$ & 3 & 1 & 3 & 1 & 3 & 4 & \\
\hline $35-39$ & & 1 & 1 & $<1$ & 1 & 1 & \\
\hline $40-44$ & & $<1$ & $<1$ & $<1$ & & $<1$ & \\
\hline$\geq 45$ & & & & & & $<1$ & \\
\hline \multicolumn{8}{|l|}{ Distance (m) } \\
\hline$<500$ & 74 & 100 & 61 & 14 & & 33 & 93 \\
\hline $500-999$ & 10 & $<1$ & 27 & 21 & & 18 & 7 \\
\hline $1000-1499$ & 3 & & 8 & 20 & 14 & 13 & \\
\hline $1500-1999$ & 9 & & 4 & 18 & 32 & 13 & \\
\hline $2000-2499$ & 3 & & 1 & 14 & 25 & 12 & \\
\hline $2500-2999$ & $<1$ & & 1 & 10 & 29 & 8 & \\
\hline $3000-3499$ & & & $<1$ & 4 & 9 & 3 & \\
\hline$\geq 3500$ & & & & 1 & 1 & 1 & \\
\hline
\end{tabular}

for construction of communication facilities along Pico del Este and Pico del Oeste (cf. Scatena 1993) are among the few sites declining in forest cover. The extent of Tabonuco forest increased dramatically, from $<3 \%$ to $>26 \%$ of the coincident study area (Table 1 ). Colorado forest increased from $31 \%$ to nearly $45 \%$, Dwarf forest changed $<1 \%$, and Palm forest declined $3 \%$.

Overlaying the 1936 and 1989 forest type maps shows the transitions among the major forest types (Table 9, Fig. 3). Areas in 1936 that were unforested primarily became Tabonuco (39\%), Colorado (18\%), Palm (20\%), and Plantation (10\%) by 1989 . Secondary forest in 1936 developed into Tabonuco $(59 \%)$, Colorado (15\%), and Palm (21\%), but seldom into Plantation (1\%). Within Colorado and Palm types, there was an interesting dynamic: $16 \%$ of the Colorado forest in 1936 became Palm and $47 \%$ of the Palm area became Colorado. A lesser extent of Palm (13\%) became Tabonuco.

These transitions led to distinctive developmental patterns for the major forest types in 1989. Approximately $80 \%$ of the modern Tabonuco forest developed on areas that were open or in secondary vegetation in 1936, $13 \%$ came from Palm forest, and only $7 \%$ was
Tabonuco in 1936 (Table 9). In contrast, $87 \%$ of the 1989 Colorado forest was continuous forest in 1936, 57\% Colorado, and 27\% Palm. Colorado also developed from Secondary (9\%) and Unforested (5\%) areas. Palm brakes developed evenly from the broadest range of vegetation, with $42 \%$ classified as Palm in 1936, but large areas developed from Unforested (11\%), Secondary $(23 \%)$, and Colorado $(21 \%)$. Plantations were established primarily on Unforested areas (79\%) or Secondary forest $(16 \%)$.

The Mantel analysis showed positive spatial autocorrelation for the changes in forest cover and in most forest types (Unforested, Secondary, Tabonuco), and negative spatial autocorrelation for the changes in Colorado and Dwarf (Table 10). The distributions of change in forest cover and in most forest types (Unforested, Tabonuco, Dwarf) were best explained by elevation, whereas the distribution of change in Colorado was best explained by distance from the LEF border, and the distribution of change in Palm was best explained by distance and slope. The distribution of change in Secondary forest was most strongly correlated with space, indicating a spatial structure to the data not explained by elevation, slope, or distance. 
TABLE 8. Correlation of 1989 forest cover and forest type in the Luquillo Experimental Forest with elevation, slope, distance to the LEF border, and space, where $r$ is the Mantel coefficient and $P$ is the significance after 1000 randomizations.

\begin{tabular}{|c|c|c|c|c|c|c|c|c|}
\hline \multirow[b]{2}{*}{ Variable } & \multicolumn{2}{|c|}{ Elevation } & \multicolumn{2}{|c|}{ Slope } & \multicolumn{2}{|c|}{ Distance } & \multicolumn{2}{|c|}{ Space } \\
\hline & $r$ & $P$ & $r$ & $P$ & $r$ & $P$ & $r$ & $P$ \\
\hline Space & 0.226 & 0.001 & 0.061 & 0.013 & -0.063 & 0.002 & & \\
\hline Cover $\dagger$ & NS & & NS & & NS & & 0.128 & 0.010 \\
\hline Cover Space & NS & & NS & & NS & & & \\
\hline Cover| Envir.§ & NS & & NS & & NS & & 0.122 & 0.012 \\
\hline Unforested & NS & & NS & & NS & & 0.123 & 0.012 \\
\hline Unforested Space & NS & & NS & & NS & & & \\
\hline Unforested | Envir. & NS & & NS & & NS & & 0.128 & 0.009 \\
\hline Secondary & 0.151 & 0.017 & NS & & NS & & 0.118 & 0.014 \\
\hline Secondary | Space & 0.129 & 0.034 & NS & & NS & & & \\
\hline Secondary Envir. & 0.145 & 0.042 & NS & & NS & & 0.086 & 0.063 \\
\hline Tabonuco & 0.423 & 0.001 & NS & & NS & & 0.269 & 0.001 \\
\hline Tabonuco I Space & 0.379 & 0.001 & NS & & 0.056 & 0.038 & & \\
\hline Tabonuco | Envir. & 0.419 & 0.001 & NS & & -0.097 & 0.003 & 0.168 & 0.001 \\
\hline Colorado & 0.233 & 0.001 & NS & & 0.146 & 0.001 & 0.022 & 0.027 \\
\hline Colorado | Space & 0.240 & 0.001 & NS & & 0.148 & 0.001 & & \\
\hline Colorado | Envir. & 0.213 & 0.001 & 0.023 & 0.020 & 0.070 & 0.001 & -0.023 & 0.014 \\
\hline Dwarf & 0.211 & 0.005 & NS & & 0.140 & 0.027 & NS & \\
\hline Dwarf | Space & 0.245 & 0.002 & NS & & 0.136 & 0.029 & DO & \\
\hline Dwarf | Envir. & 0.219 & 0.007 & NS & & NS & & -0.127 & 0.006 \\
\hline Palm & NS & & 0.071 & 0.054 & 0.060 & 0.052 & NS & \\
\hline Palm | Space & NS & & 0.072 & 0.053 & 0.060 & 0.048 & & \\
\hline Palm | Envir. & NS & & 0.071 & 0.059 & 0.069 & 0.045 & NS & \\
\hline Plantation & 0.110 & 0.063 & NS & & NS & & NS & \\
\hline Plantation | Space & 0.097 & 0.098 & NS & & NS & & & \\
\hline Plantation Envir. & 0.121 & 0.078 & NS & & NS & & NS & \\
\hline
\end{tabular}

Note: NS indicates values of $r$ that are not significant $(P>0.1)$

$\dagger$ Cover is the forest cover (all forest types).

\$ Space indicates a partial correlation controlling for space

$\S$ Envir. indicates a partial correlation controlling for the other three dependent variables.

\section{Impacts of hurricanes before 1936}

The Mantel analysis of 1936 vegetation indicated that the distributions of forest cover and most forest types (Unforested, Secondary, Dwarf) were not correlated with predicted topographic exposure to the eight wind directions, after controlling for space (Table 11, Fig. 4). Among the remaining forest types, Tabonuco tended to occur in areas topographically protected from west and southeast winds, Colorado tended to occur in areas protected from east and northeast winds, and
Palm developed in areas protected from southwest, south, and west winds.

The two dominant forest types at higher elevations, Colorado and Palm, showed complementary patterns of relative abundance on fully exposed sites (i.e., exposed for an inflection angle of $0^{\circ}$, Table 12). Palm was relatively more abundant than Colorado on sites fully exposed to east and northeast winds, whereas Colorado was relatively more abundant than Palm on sites fully exposed to west and southwest winds.

TABLE 9. Forest type transitions from 1936 to 1989 in the Luquillo Experimental Forest (coincident study area). For each transition, the first number is the percentage of the total area of the 1936 forest type, and the second number is the percentage of the total area of the 1989 forest type. For example, 39\% of all Unforested areas in 1936 became Tabonuco in 1989, and these areas made up 20\% of the total Tabonuco in 1989.

\begin{tabular}{|c|c|c|c|c|c|c|c|c|}
\hline \multirow[b]{3}{*}{1936 forest types } & \multicolumn{8}{|c|}{1989 forest types } \\
\hline & \multicolumn{2}{|c|}{$\begin{array}{c}\text { Unforested } \\
(89 \mathrm{ha})\end{array}$} & \multicolumn{2}{|c|}{$\begin{array}{c}\text { Secondary } \\
(118 \mathrm{ha})\end{array}$} & \multicolumn{2}{|c|}{$\begin{array}{l}\text { Tabonuco } \\
(1950 \text { ha) }\end{array}$} & \multicolumn{2}{|c|}{$\begin{array}{l}\text { Colorado } \\
\text { (3333 ha) }\end{array}$} \\
\hline & 1936 & 1989 & 1936 & 1989 & 1936 & 1989 & 1936 & 1989 \\
\hline Unforested (976 ha) & 5 & 52 & 7 & 60 & 39 & 20 & 18 & 5 \\
\hline Secondary (1929 ha) & 1 & 27 & 2 & 39 & 59 & 59 & 15 & 9 \\
\hline Tabonuco $(210 \mathrm{ha})$ & & & & & 65 & 7 & 24 & 2 \\
\hline Colorado (2316 ha) & 1 & 12 & $<1$ & 1 & 2 & 2 & 81 & 57 \\
\hline Dwarf ( 80 ha) & 3 & 2 & & & & & 23 & 1 \\
\hline Palm (1952 ha) & $<1$ & 7 & $<1$ & $<1$ & 13 & 13 & 47 & 27 \\
\hline
\end{tabular}


FIG. 3. Major pathways of vegetation development from 1936 to 1989 . See Tables 1,8 , and 9 for additional results. The different line types indicate the approximate percentage of 1989 forest resulting from each transition.

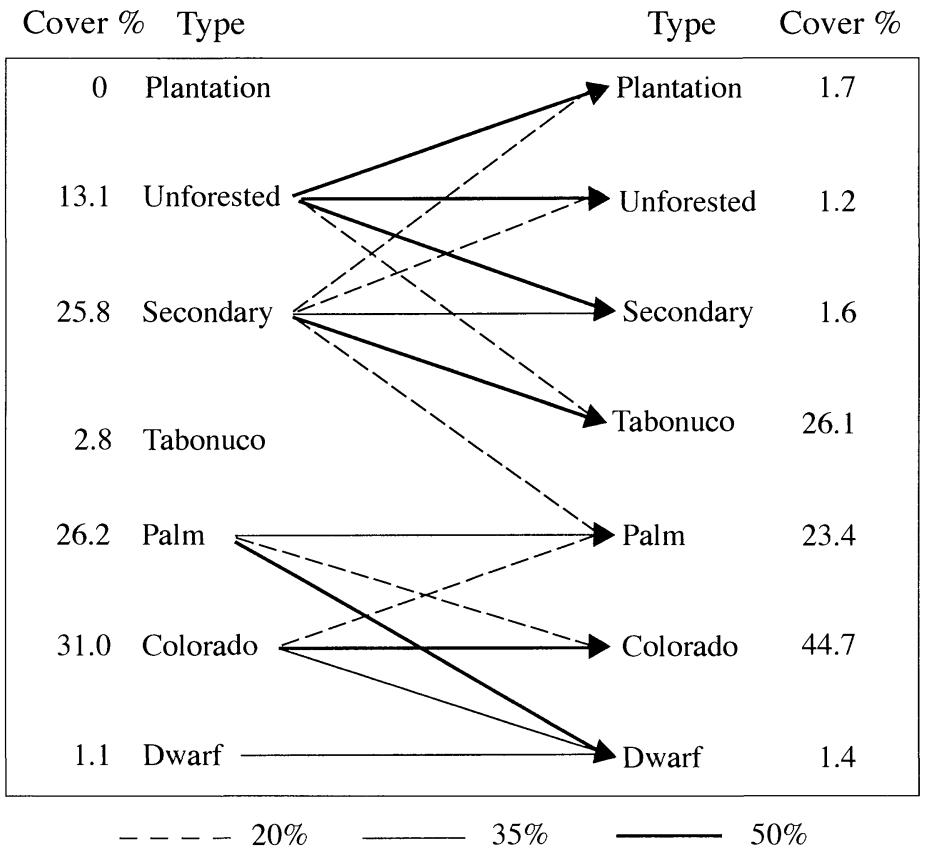

\section{DisCUSSION}

The dramatic changes in the extent, structure, and pattern of forest vegetation over the half century investigated constitute a major landscape transformation that is paralleled across much of Puerto Rico (Birdsey and Weaver 1982, 1987). These forest dynamics were driven primarily by land use and, to a much lesser extent, by hurricane impacts. These results are important as they (1) identify major factors leaving longterm imprints on the structure and function of modern ecosystems; (2) are critical to research interpretations in ecology and conservation biology; (3) have great relevance to the formulation of management policy and decision making; and (4) highlight the remarkable rate at which some tropical forest landscapes can recover from broad-scale, intensive land use activity.

\section{The 1936 vegetation in relation to land use}

In 1936, the vegetation pattern paralleled a gradient of human disturbance that declined from low elevations

TABle 9. Extended.

\begin{tabular}{|c|c|c|c|c|c|}
\hline \multicolumn{6}{|c|}{1989 forest types } \\
\hline \multicolumn{2}{|c|}{$\begin{array}{c}\text { Dwarf } \\
\text { (106 ha) }\end{array}$} & \multicolumn{2}{|c|}{$\begin{array}{c}\text { Palm } \\
\text { (1744 ha) }\end{array}$} & \multicolumn{2}{|c|}{$\begin{array}{c}\text { Plantation } \\
\text { (123 ha) }\end{array}$} \\
\hline 1936 & 1989 & 1936 & 1989 & 1936 & 1989 \\
\hline \multirow[t]{3}{*}{1} & 5 & 20 & 11 & 10 & 79 \\
\hline & & 21 & 23 & 1 & 16 \\
\hline & & 12 & 1 & & \\
\hline$<1$ & 49 & 16 & 21 & & \\
\hline 61 & 46 & 13 & 1 & & \\
\hline 2 & 39 & 38 & 42 & $<1$ & 5 \\
\hline
\end{tabular}

at the margin of the LEF to high elevations toward the center (Wadsworth 1949). The presence of agricultural and residential clearings, roads, and landslides corroborate historical evidence of pervasive human land use throughout the LEF, with a concentration of activity in the Tabonuco zone (Hill 1899, Gifford 1905; USFS, unpublished data). The vegetation pattern in 1936, consisting of extensive Unforested area and Secondary forest, limited Tabonuco forest and relatively intact Colorado and Dwarf forest, confirms that human activities affected forest conditions strongly, but differentially (Fig. 2).

Land use activity, including agriculture, grazing, logging, and mining, varied across the LEF as controlled by physiography, access, and ownership patterns (Gifford 1905, Wadsworth 1950, Scatena 1989, Garcia-Montiel and Scatena 1994). Open-land agriculture of diverse crops including sugar cane, rice, and bananas on tilled land, with pasture for cows, goats, and horses, extended broadly to $650 \mathrm{~m}$ a.s.1. (Hill 1899 , Gifford 1905; USFS, unpublished data), which coincides closely with the extent of deforested area in 1936 (Table 5). An inventory in 1934 of 30 coffee farms in mountainous terrain across Puerto Rico indicated that they averaged 75 ha of crops, wood pasture, permanent pasture, woodland, and wasteland and buildings in the ratio 12:4:4:1:1 (Garcia 1936). Agriculture often had severe impacts. Nutrient depletion encouraged a process of ongoing field abandonment and forest clearance. Overgrazing, cultivation, and road building combined with heavy precipitation and steep slopes to produce widespread erosion and landslides. Soils on old 
TABLE 10. Correlation of forest cover and forest type changes from 1936 to 1989 in the Luquillo Experimental Forest (coincident study area) with elevation, slope, distance to the LEF border, and space, where $r$ is the Mantel coefficient and $P$ is the significance after 1000 randomizations.

\begin{tabular}{|c|c|c|c|c|c|c|c|c|}
\hline \multirow[b]{2}{*}{ Variable } & \multicolumn{2}{|c|}{ Elevation } & \multicolumn{2}{|c|}{ Slope } & \multicolumn{2}{|c|}{ Distance } & \multicolumn{2}{|c|}{ Space } \\
\hline & $r$ & $P$ & $r$ & $P$ & $r$ & $P$ & $r$ & $P$ \\
\hline Space & 0.226 & 0.001 & 0.061 & 0.013 & -0.063 & 0.002 & & \\
\hline Covert & 0.280 & 0.001 & -0.071 & 0.039 & 0.073 & 0.012 & 0.163 & 0.001 \\
\hline Cover $\mid$ Space $\neq$ & 0.254 & 0.001 & -0.080 & 0.017 & 0.084 & 0.003 & & \\
\hline Cover| Envir.§ & 0.253 & 0.001 & -0.068 & 0.040 & NS & & 0.109 & 0.001 \\
\hline Unforested & 0.362 & 0.001 & NS & & NS & & 0.273 & 0.001 \\
\hline Unforested | Space & 0.313 & 0.001 & -0.096 & 0.072 & NS & & & \\
\hline Unforested Envir. & 0.348 & 0.001 & NS & & -0.096 & 0.052 & 0.194 & 0.001 \\
\hline Secondary & 0.230 & 0.001 & NS & & 0.057 & 0.090 & 0.230 & 0.001 \\
\hline Secondary $\mid$ Space & 0.185 & 0.001 & NS & & 0.071 & 0.030 & & \\
\hline Secondary | Envir. & 0.182 & 0.001 & NS & & NS & & 0.190 & 0.001 \\
\hline Tabonuco & 0.392 & 0.001 & NS & & NS & & 0.264 & 0.001 \\
\hline Tabonuco Space & 0.347 & 0.001 & NS & & NS & & & \\
\hline Tabonuco | Envir. & 0.390 & 0.001 & NS & & -0.102 & 0.005 & 0.168 & 0.001 \\
\hline Colorado & -0.082 & 0.070 & NS & & 0.079 & 0.064 & -0.121 & 0.003 \\
\hline Colorado Space & NS & & NS & & 0.071 & 0.084 & & \\
\hline Colorado | Envir. & -0.104 & 0.049 & NS & & 0.109 & 0.017 & -0.088 & 0.017 \\
\hline Dwarf & 0.171 & 0.021 & NS & & 0.151 & 0.033 & -0.089 & 0.094 \\
\hline Dwarf | Space & 0.204 & 0.006 & NS & & 0.146 & 0.035 & & \\
\hline Dwarf | Envir. & 0.165 & 0.032 & NS & & NS & & -0.177 & 0.016 \\
\hline Palm & NS & & 0.076 & 0.090 & 0.066 & 0.070 & NS & \\
\hline Palm Space & NS & & 0.075 & 0.091 & 0.067 & 0.061 & & \\
\hline Palm | Envir. & NS & & 0.074 & 0.092 & 0.075 & 0.065 & NS & \\
\hline
\end{tabular}

Note: NS indicates values of $r$ that are not significant $(P>0.1)$.

$\dagger$ Cover is the forest cover (all forest types).

$¥$ | Space is a partial correlation controlling for space.

$\S \mid$ Envir. is a partial correlation controlling for the other three dependent variables.

TABLE 11. Correlation of 1936 forest cover and forest type in the Luquillo Experimental Forest (entire study area) with predicted topographic exposure to wind using the EXPOS model, where $r$ is the Mantel coefficient and $P$ is the significance after 1000 randomizations.

\begin{tabular}{|c|c|c|c|c|c|c|c|c|c|c|}
\hline \multirow[b]{3}{*}{ Variable } & \multicolumn{10}{|c|}{ Simulated wind direction } \\
\hline & \multicolumn{2}{|c|}{ North } & \multicolumn{2}{|c|}{ Northeast } & \multicolumn{2}{|c|}{ East } & \multicolumn{2}{|c|}{ Southeast } & \multicolumn{2}{|c|}{ South } \\
\hline & $r$ & $P$ & $r$ & $P$ & $r$ & $P$ & $r$ & $P$ & $r$ & $P$ \\
\hline $\begin{array}{l}\text { Cover } \dagger \\
\text { Cover } \\
\text { Cover }\end{array}$ & $\begin{array}{l}\text { NS } \\
\text { NS } \\
\text { NS }\end{array}$ & & $\begin{array}{l}\text { NS } \\
\text { NS } \\
\text { NS }\end{array}$ & & $\begin{array}{l}\text { NS } \\
\text { NS } \\
\text { NS }\end{array}$ & & $\begin{array}{l}-0.044 \\
-0.061 \\
-0.057\end{array}$ & $\begin{array}{l}0.086 \\
0.022 \\
0.031\end{array}$ & $\begin{array}{l}-0.055 \\
-0.078 \\
-0.070\end{array}$ & $\begin{array}{l}0.032 \\
0.004 \\
0.009\end{array}$ \\
\hline $\begin{array}{l}\text { Unforested } \\
\quad \text { Unforested | Space } \\
\text { Unforested | Envir. }\end{array}$ & $\begin{array}{l}\text { NS } \\
\text { NS } \\
\text { NS }\end{array}$ & & $\begin{array}{l}\text { NS } \\
\text { NS } \\
\text { NS }\end{array}$ & & $\begin{array}{l}\text { NS } \\
\text { NS } \\
\text { NS }\end{array}$ & & $\begin{array}{c}\text { NS } \\
-0.088 \\
-0.087\end{array}$ & $\begin{array}{l}0.050 \\
0.051\end{array}$ & $\begin{array}{c}\text { NS } \\
-0.107 \\
-0.106\end{array}$ & $\begin{array}{l}0.024 \\
0.025\end{array}$ \\
\hline \begin{tabular}{l|l} 
Secondary & \\
Secondary & Space \\
Secondary & Envir.
\end{tabular} & $\begin{array}{l}\text { NS } \\
\text { NS } \\
\text { NS }\end{array}$ & & $\begin{array}{l}\text { NS } \\
\text { NS } \\
\text { NS }\end{array}$ & & $\begin{array}{l}\text { NS } \\
\text { NS } \\
\text { NS }\end{array}$ & & $\begin{array}{l}0.057 \\
\text { NS } \\
\text { NS }\end{array}$ & 0.068 & $\begin{array}{l}\text { NS } \\
\text { NS } \\
\text { NS }\end{array}$ & \\
\hline $\begin{array}{l}\text { Tabonuco } \\
\text { Tabonuco } \\
\text { Tabonuco } \\
\text { Space } \\
\text { Envir. }\end{array}$ & $\begin{array}{l}-0.106 \\
-0.100 \\
-0.093\end{array}$ & $\begin{array}{l}0.039 \\
0.055 \\
0.074\end{array}$ & $\begin{array}{l}-0.110 \\
-0.105 \\
-0.098\end{array}$ & $\begin{array}{l}0.045 \\
0.054 \\
0.073\end{array}$ & $\begin{array}{l}\text { NS } \\
\text { NS } \\
\text { NS }\end{array}$ & & $\begin{array}{l}\text { NS } \\
0.076 \\
0.080\end{array}$ & $\begin{array}{l}0.096 \\
0.080\end{array}$ & $\begin{array}{l}\text { NS } \\
\text { NS } \\
\text { NS }\end{array}$ & \\
\hline $\begin{array}{l}\text { Colorado } \\
\text { Colorado | Space } \\
\text { Colorado | Envir. }\end{array}$ & $\begin{array}{l}\text { NS } \\
\text { NS } \\
\text { NS }\end{array}$ & & $\begin{array}{l}\text { NS } \\
\text { NS } \\
0.050\end{array}$ & 0.046 & $\begin{array}{l}0.045 \\
0.045 \\
0.047\end{array}$ & $\begin{array}{l}0.071 \\
0.071 \\
0.056\end{array}$ & $\begin{array}{l}\text { NS } \\
\text { NS } \\
\text { NS }\end{array}$ & & $\begin{array}{l}\text { NS } \\
\text { NS } \\
\text { NS }\end{array}$ & \\
\hline \begin{tabular}{l|l} 
Dwarf & \\
Dwarf & Space \\
Dwarf & Envir.
\end{tabular} & $\begin{array}{l}\text { NS } \\
\text { NS } \\
\text { NS }\end{array}$ & & $\begin{array}{l}\text { NS } \\
\text { NS } \\
\text { NS }\end{array}$ & & $\begin{array}{l}\text { NS } \\
\text { NS } \\
\text { NS }\end{array}$ & & $\begin{array}{l}\text { NS } \\
\text { NS } \\
\text { NS }\end{array}$ & & $\begin{array}{l}\text { NS } \\
\text { NS } \\
\text { NS }\end{array}$ & \\
\hline $\begin{array}{l}\text { Palm } \\
\text { Palm | Space } \\
\text { Palm Envir. }\end{array}$ & $\begin{array}{l}\text { NS } \\
\text { NS } \\
\text { NS }\end{array}$ & & $\begin{array}{l}\text { NS } \\
\text { NS } \\
\text { NS }\end{array}$ & & $\begin{array}{l}\text { NS } \\
\text { NS } \\
\text { NS }\end{array}$ & & $\begin{array}{l}\text { NS } \\
\text { NS } \\
\text { NS }\end{array}$ & & $\begin{array}{l}0.094 \\
0.107 \\
0.102\end{array}$ & $\begin{array}{l}0.003 \\
0.001 \\
0.001\end{array}$ \\
\hline
\end{tabular}

Note: NS indicates values of $r$ that are not significant $(P>0.1)$.

$\dagger$ Cover is the forest cover (all forest types).

$\$$ Space indicates the partial correlation controlling for space.

$\S \mid$ Envir. indicates the partial correlation controlling for elevation, slope, distance to the LEF border, and space. 

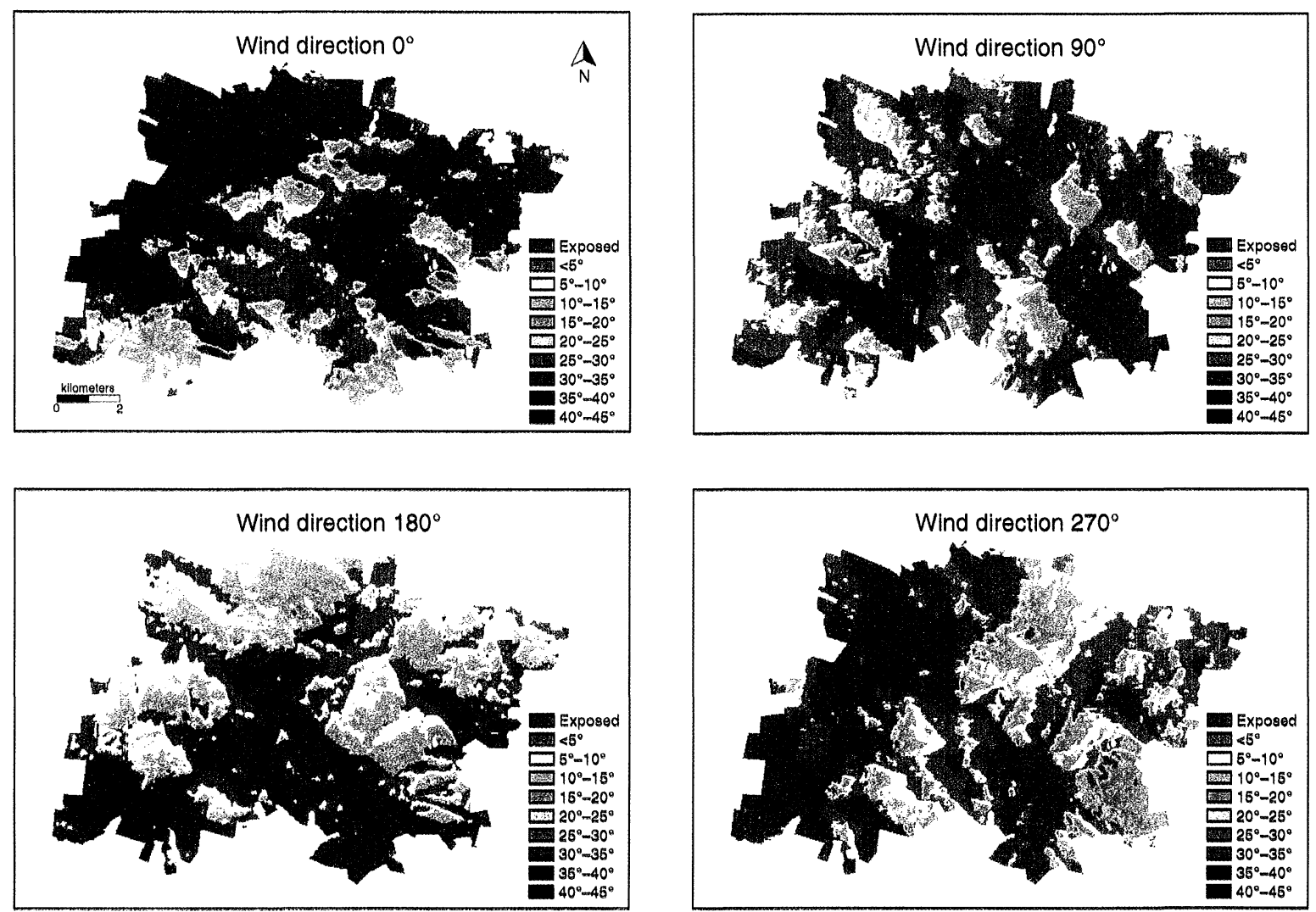

Fig. 4. Predicted topographic exposure in the Luquillo Experimental Forest using the EXPOS model. Maps show $5^{\circ}$ protection classes for four simulated wind directions: north $\left(0^{\circ}\right)$, east $\left(90^{\circ}\right)$, south $\left(180^{\circ}\right)$, and west $\left(270^{\circ}\right)$.

TABLE 11. Extended.

\begin{tabular}{|c|c|c|c|c|c|}
\hline \multicolumn{6}{|c|}{ Simulated wind direction } \\
\hline \multicolumn{2}{|c|}{ Southwest } & \multicolumn{2}{|c|}{ West } & \multicolumn{2}{|c|}{ Northwest } \\
\hline$r$ & $P$ & $r$ & $P$ & $r$ & $P$ \\
\hline NS & & NS & & NS & \\
\hline NS & & NS & & NS & \\
\hline NS & & NS & & NS & \\
\hline NS & & NS & & NS & \\
\hline NS & & NS & & NS & \\
\hline NS & & NS & & NS & \\
\hline NS & & NS & & NS & \\
\hline NS & & NS & & NS & \\
\hline-0.058 & 0.086 & NS & & NS & \\
\hline NS & & 0.091 & 0.075 & NS & \\
\hline NS & & 0.095 & 0.063 & NS & \\
\hline NS & & 0.108 & 0.041 & NS & \\
\hline NS & & NS & & -0.049 & 0.052 \\
\hline NS & & NS & & -0.048 & 0.054 \\
\hline NS & & NS & & -0.044 & 0.086 \\
\hline NS & & NS & & NS & \\
\hline NS & & NS & & NS & \\
\hline NS & & NS & & NS & \\
\hline 0.165 & 0.001 & 0.063 & 0.048 & NS & \\
\hline 0.169 & 0.001 & 0.067 & 0.039 & NS & \\
\hline 0.161 & 0.001 & 0.054 & 0.079 & NS & \\
\hline
\end{tabular}

farm areas were termed "ruinate" (Hill 1899) to describe the severe compaction, erosion, and fertility loss (Marrero 1950).

At higher elevations lay extensive Secondary forest established on abandoned farmland, coffee plantations, and areas affected by cutting for fuelwood and charcoal, or by hurricane damage (Fig. 2, Table 5; GarciaMontiel and Scatena 1994). Agriculture peaked in 1900 , after which large areas were abandoned, especially on steep slopes and at high elevations. Coffee plantations, which consist of an open overstory of shade trees and an understory of coffee, often formed the upper tier of farms (Hill 1899). These semiforested areas are difficult to distinguish from intact woodland (Gifford 1905) and may be included with Secondary and Tabonuco forest on our 1936 map.

Forest cutting continued to alter forest composition and structure drastically through 1936 (Murphy 1916, Wadsworth 1963). Logging varied with access, as controlled by slope and distance from trails, and was most intense in the Tabonuco forest (Murphy 1916, Wadsworth 1952, 1963). At higher elevations, cutting was selective by species (Gifford 1905, Murphy 1916, Wadsworth 1950; USFS 1985); in remote Colorado forests, it may have been limited to as little as one tree per acre (Wadsworth 1952, 1963). However, even se- 
TABLE 12. Relative distributions of Colorado and Palm forest types in the Luquillo Experimental Forest as a function of predicted topographic exposure to wind using the EXPOS model. Values show the percentage of each forest type on fully exposed sites, and the ratio of the percentage of Palm to the percentage of Colorado $(\mathrm{P} / \mathrm{C})$.

\begin{tabular}{|c|c|c|c|c|c|c|c|c|c|}
\hline \multirow[b]{2}{*}{$\begin{array}{l}\text { Wind } \\
\text { direction }\end{array}$} & \multicolumn{3}{|c|}{1936 entire } & \multicolumn{3}{|c|}{1936 coincident } & \multicolumn{3}{|c|}{1989 coincident } \\
\hline & $\begin{array}{c}\text { Colorado } \\
(\%)\end{array}$ & $\begin{array}{c}\text { Palm } \\
(\%)\end{array}$ & $\begin{array}{l}\text { Ratio } \\
\text { (P/C) }\end{array}$ & $\begin{array}{c}\text { Colorado } \\
(\%)\end{array}$ & $\begin{array}{c}\text { Palm } \\
(\%)\end{array}$ & $\begin{array}{l}\text { Ratio } \\
(\mathrm{P} / \mathrm{C})\end{array}$ & $\begin{array}{c}\text { Colorado } \\
(\%)\end{array}$ & $\begin{array}{c}\text { Palm } \\
(\%)\end{array}$ & $\begin{array}{l}\text { Ratio } \\
(\mathrm{P} / \mathrm{C})\end{array}$ \\
\hline North & 49.5 & 49.9 & 1.01 & 49.8 & 54.9 & 1.10 & 52.8 & 50.3 & 0.95 \\
\hline Northeast & 47.4 & 52.8 & 1.11 & 42.5 & 50.7 & 1.19 & 43.9 & 48.9 & 1.11 \\
\hline East & 37.3 & 51.2 & 1.37 & 29.8 & 45.8 & 1.54 & 30.9 & 45.7 & 1.48 \\
\hline Southeast & 45.1 & 46.1 & 1.02 & 40.7 & 40.2 & 0.99 & 39.0 & 46.2 & 1.18 \\
\hline South & 48.9 & 37.3 & 0.76 & 48.0 & 37.1 & 0.77 & 45.4 & 41.3 & 0.91 \\
\hline Southwest & 44.8 & 28.0 & 0.62 & 48.3 & 32.7 & 0.68 & 47.6 & 36.2 & 0.76 \\
\hline West & 58.6 & 35.8 & 0.61 & 62.3 & 43.2 & 0.69 & 61.9 & 45.9 & 0.74 \\
\hline Northwest & 58.4 & 41.4 & 0.71 & 63.9 & 51.6 & 0.81 & 62.1 & 50.1 & 0.81 \\
\hline
\end{tabular}

lective cutting altered forest composition. Ausubo, a valuable timber species cut widely across the LEF, was described as "rare" or "nearly extinct" by AD 1900 (Murphy 1916; USFS, unpublished data). In addition to timber, the Tabonuco and Colorado forests provided charcoal through the 1940s (Gifford 1905, Scatena 1989, Garcia-Montiel 1991).

\section{Importance of hurricane impacts in 1936}

The 1936 aerial photographs show no definitive evidence of prior hurricane impacts (e.g., blowdowns from the 1928 or 1932 storms). The 1956 hurricane, the only major storm during the $50-y r$ period of this study, was reported to have a minor impact on the LEF (Wadsworth and Englerth 1959), although surrounding towns sustained considerable damage (E. Boose, unpublished data). The hurricane of 1899 is described as the most destructive of three late 19th-century storms to hit Puerto Rico (Murphy 1916). However, none of the contemporary surveys of forests in Puerto Rico (Hill 1899) or the LEF (Gifford 1905) mentions damage from the storm or cites hurricane impacts as important in determining forest condition.

The San Felipe hurricane in 1928 produced gusts of $240 \mathrm{k} / \mathrm{h}$ in San Juan (Scatena and Larsen 1991), and the San Ciprian storm of 1932 is considered by Weaver $(1986,1987)$ to be the most powerful hurricane to affect the LEF in this century. Interpretations of these storms' effects are inconsistent: they have been variously described as blowing down some of the best forest in the LEF (USFS, unpublished data), being more severe than Hurricane Hugo in 1989 (Weaver 1983), and creating only minor damage (Wadsworth and Englerth 1959). Detailed acquisition records of the U.S. Forest Service indicate only scattered storm damage in the 1930s.

Because there was no clear evidence of broad-scale hurricane damage in the 1936 photographs or historical records, we compared the vegetation pattern with predicted topographic exposure to wind to evaluate correspondence in patterns. The Mantel test showed no significant correlation between forest cover and predicted exposure. The rapid recovery and regrowth of vegetation probably served to conceal any canopy dam- age caused by earlier hurricanes in the 1936 aerial photographs.

The positive correlation between Tabonuco and areas protected from west and southeast winds reflects the fact that, in 1936, Tabonuco was confined almost entirely to the northeastern portion of the LEF. This distribution probably resulted from greater land use in the natural Tabonuco zone along the southern and western borders of the LEF (see Fig. 2; Scatena 1989).

Meteorological records from the nearby city of San Juan indicate that peak winds in the hurricanes of 1916 , 1928, and 1932 came from the northeast (National Climatic Data Center, unpublished data). The Mantel analysis showed that, in 1936, the distribution of Colorado forest was correlated with areas protected from east winds, whereas Palm was relatively more abundant than Colorado on sites fully exposed to northeast and east winds. This pattern may reflect the impacts of earlier hurricanes, because Palm often plays a successional role on sites disturbed by cutting or wind disturbance (Murphy 1916, Ewel and Whitmore 1973). The pattern may also reflect greater orographic rainfall on these same slopes, because Palm does well on saturated soils (Ewel and Whitmore 1973). In 1989, after a period of reduced human disturbance and fewer hurricanes, there were fewer large patches of Palm, although it persisted in narrow stands in drainageways (see Fig. 2). Palm in 1989 was still relatively more abundant than Colorado on sites fully exposed to the northeast and east, perhaps in part because of the 1956 hurricane, in which peak recorded winds in San Juan came from the east-northeast (National Climatic Data Center, unpublished data).

Other disturbances influenced local, rather than broad-scale, vegetation pattern. Fire was used to clear forests and to maintain open agricultural areas, and may have spread into adjacent secondary and intact forest (USFS, unpublished data). Landslides have been strongly controlled by slope, bedrock, and land use over the past $50 \mathrm{yr}$ (Guariguata and Larsen 1989). Under intense forest clearance, cultivation, and trail construction, it is likely that the late 19th and early 20th centuries experienced more frequent and severe land- 
slides than under recent, forested conditions (Guariguata 1990, Larsen and Parks 1997).

\section{Forest landscape dynamics from 1936 to 1989}

The great increase in forest cover over the last 50 yr resulted from farm abandonment in the late 19th and 20th centuries (Birdsey and Weaver 1982, Zimmerman et al. 1995). Across Puerto Rico, massive rural migration during this period led to an increase in forest area from $<10 \%$ to $\sim 30 \%$ (Horn 1946, USFS 1985, Birdsey and Weaver 1987). The developing forests continued to be influenced by farming, fuelwood production, silviculture, forest planting, road construction, and recreation. The U.S. Forest Service objective in the LEF has been to reforest or encourage forest growth on all agricultural lands, improve forest production, and manage lands for diverse natural resources (Wadsworth 1950 , USFS 1985). By the mid 1940s, 2800 ha of land had been planted in highly varying densities (Marrero 1947). To improve timber growth, the U.S. Forest Service thinned 20-125 ha annually through the 1970s (Wadsworth 1963) and undertook extensive charcoal and fuelwood production through the 1940s, when the population of Puerto Rico consumed $>1 \times 10^{6}$ cords of firewood and charcoal annually (Teesdale and Girard 1945). These activities were highly selective by species, and certainly impacted forest composition and structure (Scatena 1989, Garcia-Montiel 1991).

In the 1980s and 1990s, new cultural values and enhanced appreciation of tropical forests have altered land use practices greatly in the LEF. U.S. Forest Service silvicultural activity has largely ceased, and recreation, scientific research, and educational activities have increased. Therefore, the trend for the future should be development of progressively older forests, mediated by natural disturbance processes.

\section{Implications of land-use history and forest change in the $L E F$}

The vegetation transformation of the last half century has many implications for understanding the tropical forest ecosystems of the LEF. Foremost is the recognition that people have played an important and dynamic role in controlling vegetation patterns through a gradient of use, ranging from intensive agriculture at low elevations, through crop planting and fuelwood extraction at middle elevations, to selective tree removal at upper elevations. These impacts have left clear legacies in forest structure, composition, and function, and influence the manner in which we interpret forest processes.

Secondary forests in the LEF tend to include fewer species and more introduced species than do primary forests (Lugo 1988, Waide and Lugo 1992). Species assemblages and forest structure may differentiate contrasting land use on adjacent sites as shown by striking differences across a 9-ha mapped Tabonuco forest at the El Verde Field Station (Zimmerman et al. 1995).
Land use may also have unexpected species level effects. Logging has eliminated big trees with bole cavities from the Tabonuco forest, which were preferred nest site for the endangered Puerto Rican Parrot. The few remaining pairs of parrots are restricted to Colorado forest, which is less preferable in environment and food supply, but is a major site of suitable cavities (Snyder et al. 1987; R. Waide, personal communication).

Second-growth forests across Puerto Rico sequester large amounts of carbon into biomass and soils that serve to balance, to some slight extent, extensive deforestation occurring elsewhere in tropical regions (Brown and Lugo 1990). Prior land use, such as farming and coffee plantations, influences modern biogeochemistry as well as hydrology and stream chemistry (Garcia-Montiel and Scatena 1994; J. Zimmermann, personal communication).

Finally, ubiquitous human activity across this mountainous landscape mandates that all research, management decisions, and ecological interpretations incorporate an awareness of land use history. Despite compelling field and historical evidence of land use, there has been a tendency to interpret forest structure and dynamics largely in natural terms. Thus, the even and low canopy structure of the Tabonuco forest has been interpreted as either a consequence of repeated hurricane impact or as an adaptation of the forest ecosystem to minimize wind damage and maximize energy capture (Odum 1970, Brown et al. 1983). Our current study and prior accounts (cf. Gifford 1905) suggest that, with the exception of small areas in the northeastern LEF, the Tabonuco forest is newly developed on prior agricultural or cutover sites. Thus, the low and simple structure may be simply a consequence of the secondary succession, a conclusion supported by descriptions of primary old-growth Tabonuco forest as multistoried with emergent trees (Gleason and Cook 1926, Wadsworth 1952, Crow and Weaver 1977). Similarly, the composition and relative species abundance of the Tabonuco forest is probably more a consequence of diverse land use activities and revegetation, possibly interacting with occasional wind damage, than a result of frequent, low-intensity hurricane impacts (cf. Doyle 1981).

As the extent of forest cover and height of forest has increased during the 20th century, the landscape has indeed become increasingly susceptible to hurricane impacts. The damage inflicted by Hurricane Hugo in 1989 (Walker et al. 1992, Boose et al. 1994) is an indication that the disturbance regime of the LEF is gradually shifting from human-dominated to increasingly dominated by natural processes. However, analysis of aerial photographs in this study, and results of post-Hugo vegetation dynamics (Zimmerman et al. 1994), indicate that the structural and compositional legacies of land use are not easily erased by subsequent forest growth or wind damage. 


\section{Conclusion}

Studies of temperate forests frequently suggest that modern landscapes provide only a momentary snapshot of a mosaic pattern that has been shaped and continues to respond to varying human impacts. Current studies in tropical regions indicate that similar impacts have transformed many forest ecosystems and that the legacies of land use may persist in terms of structure, composition, and function (Brown et al. 1992). The present study underscores the magnitude and rapidity of these changes and the need to incorporate a historical perspective in understanding modern forest patterns. Since the photographs used in this study were taken, the forest landscape of the LEF was severely damaged by Hurricane Hugo in 1989 (Boose et al. 1994), and again by Hurricane Georges in 1998, with major impacts to forest structure (Brokaw and Grear 1991), composition (Zimmerman et al. 1994), and process (Scatena 1993). The resulting mosaic of damage and the subsequent pattern of regrowth were, in part, dependent on the structural and compositional patterns resulting from prior land use. Certainly, natural disturbance, human activity, and environmental gradients continue to interact in a complex and dynamic fashion in this tropical landscape. Consequently, future ecological research and development of management policies in the LEF need to be based on an awareness of past human disturbance, ecosystem resilience to diverse disturbance processes, ongoing changes in the relative importance of human and natural processes, and a strong legacy of historical dynamics. Increasingly, research across the Old and New World tropics underlines the importance of long-term perspectives on human and natural disturbance.

\section{ACKNOWLEDGMENTS}

This study and manuscript were greatly aided by advice and critical comments from D. Garcia-Montiel, R. Kern, R. Lent, A. Lugo, G. Motzkin, F. Scatena, J. Thomlinson, D. Urban, F. Wadsworth, R. Waide, L. Walker, P. Weaver, P. Wilson, and J. Zimmerman. Support was provided by the National Science Foundation-funded LTER programs at the University of Puerto Rico and Harvard Forest (BSR 88/9411902, BSR 88/94-11764), the U.S. Forest Service, International Institute for Tropical Forestry, and the A. W. Mellon Foundation.

\section{Literature Cited}

Basnet, K., G. E. Likens, F. N. Scatena, and A. E. Lugo. 1992. Hurricane Hugo: damage to a tropical rain forest in Puerto Rico. Journal of Tropical Ecology 8:47-55.

Bates, C. Z. 1930. Hurricane damage to Porto Rican forests. Journal of Forestry 28:772-774.

Binford, M. W., M. Brenner, T. J. Whitmore, A. HigueraGundy, E. S. Deevey, and B. Leyden. 1987. Ecosystems, paleoecology and human disturbance in subtropical and tropical America. Quaternary Science Reviews 6:1 15-128.

Birdsey, R. A., and P. L. Weaver. 1982. The forest resources of Puerto Rico. U.S. Department of Agriculture Forest Service Resource Bulletin SO-85.

Birdsey, R. A., and P. L. Weaver. 1987. Forest area trends in Puerto Rico. U.S. Department of Agriculture Forest Service Research Note 50-331.
Boose, E. R., D. R. Foster, and M. Fluet. 1994. Hurricane impacts to tropical and temperate forest landscapes. Ecological Monographs 64:369-400.

Brokaw, N. V. L., and J. S. Grear. 1991. Forest structure before and after Hurricane Hugo at three elevations in the Luquillo Mountains, Puerto Rico. Biotropica 23:386-391.

Brown, S., and A. Lugo. 1990. Tropical secondary forests. Journal of Tropical Ecology 5:1-32.

Brown, S., A. E. Lugo, S. Silander, and L. Liegel. 1983. Research history and opportunities in the Luquillo Experimental Forest. U.S. Department of Agriculture General Technical Report SO-44.

Brown, S., A. E. Lugo, and J. Wisnewski. 1992. Missing carbon dioxide. Science 257:11.

Crow, R. R., and P. L. Weaver. 1977. Tree growth in a moist tropical forest of Puerto Rico. U.S. Department of Agriculture Forest Service Research Paper ITF-22.

Doyle, T. W. 1981. The role of disturbance in the gap dynamics of a montane rain forest: an application of a tropical forest succession model. Pages 56-73 in D. C. West, H. H. Shugart, and D. Botkin, editors. Forest succession: concepts and application. Springer-Verlag, New York, New York, USA.

Eastman, R. 1993. IDRISI Geographic Information Systems. Clark University, Department of Geography, Worcester, Massachusetts, USA.

Ewel, J. J., and J. L. Whitmore. 1973. The ecological life zones of Puerto Rico and the U.S. Virgin Islands. U.S. Department of Agriculture Forest Service Research Paper ITF-18.

Foster, D. R. 1993. Land-use history and forest transformations in Central New England. Pages 91-110 in M. J. McDonnell and S. T. A. Pickett, editors. Humans as components of ecosystems. Springer-Verlag, New York, New York, USA.

Foster, D. R., J. D. Aber, J. M. Melillo, R. D. Bowden, and F. A. Bazzaz. 1997. Temperate forest response to natural catastrophic disturbance and chronic anthropogenic stress. BioScience 47:437-445.

Foster, D. R., and E. R. Boose. 1995. Hurricane disturbance regimes in temperate and tropical forest ecosystems. Pages 305-339 in M. Coutts, editor. Wind effects on trees, forests and landscapes. Cambridge University Press, Cambridge, UK.

Foster, D. R., G. Motzkin, and B. Slater. 1998. Land-use history as long-term broad-scale disturbance: regional forest dynamics in central New England. Ecosystems 1:96119.

Foster, D. R., D. A. Orwig, and J. S. McLachlan. 1996. Ecological and conservation insights from reconstructive studies of temperate old-growth forests. Trends in Ecology and Evolution 11:419-424.

Garcia, J. M. 1936. A farm management study of 224 coffee farms in Puerto Rico, 1934. Thesis. Cornell University, Ithaca, New York, USA.

Garcia-Montiel, D. 1991. The effect of human activity on the structure and composition of a tropical forest in Puerto Rico. Thesis. University of Puerto Rico, Rio Piedras, Puerto Rico.

Garcia-Montiel, D., and F. N. Scatena. 1994. The effect of human activity on the structure and composition of a tropical forest in Puerto Rico. Forest Ecology and Management 63:57-78.

Gifford, J. C. 1905. The Luquillo Forest Reserve, Porto Rico. U.S. Department of Agriculture Bureau of Forestry Bulletin Number 54.

Gleason, H. A., and M. T. Cook. 1926. Scientific survey of Porto Rico and the Virgin Islands. III. Plant ecology of Porto Rico. New York Academy of Sciences, Albany, New York, USA. 
Gomez-Pompa, A. 1984. Tropical deforestation and Maya silviculture: an ecological paradox. Tulane Studies in Zoology and Botany 26:19-37.

Gomez-Pompa, A., and A. Kaus. 1992. Taming the wilderness myth. BioScience 42:271-279.

Guariguata, M. 1990. Landslide disturbance and forest regeneration in the Upper Luquillo Mountains of Puerto Rico. Journal of Ecology 78:814-832.

Guariguata, M. R., and M. C. Larsen. 1989. Preliminary map showing locations of landslides in El Yungue Quadrangle, Puerto Rico. U.S. Geological Survey Open-file Report 89257.

Hill, R. T. 1899. Notes on the forest conditions of Porto Rico. U.S. Department of Agriculture Division of Forestry Bulletin Number 25.

Holdridge, L. R. 1939. Forestry in Puerto Rico. Caribbean Forester 1:7-11.

Horn, C. L. 1946. Plant resources of Puerto Rico. Globe Press, New York, New York, USA.

Larsen, M. C., and J. E. Parks. 1997. How wide is a road? The association of roads and mass-wasting in a forested montane environment. Earth Surface Processes and Landforms 22:835-848.

Lugo, A. E. 1988. Estimating reductions in the diversity of tropical forest species. Pages 58-70 in E. O. Wilson, editor. Biodiversity. National Academy Press, Washington, D.C., USA.

1992. Comparison of tropical tree plantations with secondary forests of similar age. Ecological Monographs 62: $1-41$.

- 1994. Preservation of primary forests in the Luquillo Mountains, Puerto Rico. Conservation Biology 8:11221131

Manly, B. F. J. 1997a. Randomization, bootstrap and Monte Carlo methods in Biology. Second edition. Chapman and Hall, New York, New York, USA.

1997b. RT: a program for randomization testing. Version 2.1. Centre for Applications of Statistics and Mathematics, University of Otago, Dunedin, New Zealand.

Mantel, N. 1967. The detection of disease clustering and a generalized regression approach. Cancer Research 27:209_ 220.

Marrero, J. 1947. Forest planting in the Caribbean National Forest: past experience as a guide for the future. Thesis. University of Michigan, Ann Arbor, Michigan, USA.

1950. Results of forest planting in the insular forest of Puerto Rico. Caribbean Forester 11:107-147.

McDowell, W. H., W. B. Bowden, and C. E. Asbury. 1992. Riparian nitrogen dynamics in two geomorphologically distinct tropical rain forest watersheds: subsurface solute patterns. Biogeochemistry 18:53-75.

Meggars, B. J. 1992. Prehistoric population density in the Amazon Basin. Pages 197-205 in J. W. Verano and D. H. Ubelaker, editors. Disease and demography in the Americas. Smithsonian Institution Press, Washington, D.C., USA.

Motzkin, G., D. R. Foster, A. Allen, J. Harrod, and R. D. Boone. 1996. Controlling site to evaluate history: vegetation patterns of a New England sand plain. Ecological Monographs 66:345-365.

Murphy, L. S. 1916. Forests of Porto Rico, past, present, and future and their physical and economic environment. U.S. Department of Agriculture Bulletin 354, Washington, D.C., USA.

Northrup, L. A., and S. P. Horn. 1996. Pre-Columbian agriculture and forest disturbance in Costa Rica: paleoecological evidence from two lowland rainforest lakes. The Holocene 6:289-300.

Odum, H. T. 1970. The El Verde study area and the rain forest systems of Puerto Rico. Pages B-3-B-32 in H. T.
Odum and R. F. Pigeon, editors. A tropical rain forest. U.S. Atomic Energy Commission.

Roosevelt, A. C., R. A. Housley, M. Imazio da Silveira, S Maranca, and R. Johnson. 1991. Eighth Millenium pottery from a prehistoric shell midden in the Brazilian Amazon. Science 254: 1621-1624.

Salivia, L. A. 1972. Historia de los Temporales de Puerto Rico y las Antillas, 1492-1970. Editorial Edil, University of Puerto Rico, Rio Piedras, Puerto Rico.

Scatena, F. N. 1989. An introduction to the physiography and history of the Bisley Experimental Watersheds in the Luquillo Mountains of Puerto Rico. U. S. Department of Agriculture Forest Service General Technical Report SO72.

1993. The management of Luquillo elfin cloud forest ecosystems: irreversible decisions in a nonsubstitutable ecosystem. Pages 191-198 in L. S. Hamilton, J. O. Juvik, and F. N. Scatena, editors. Tropical montane cloud forests. East-West Center, Honolulu, Hawaii, USA.

Scatena, F. N., and M. C. Larsen. 1991. Physical aspects of Hurricane Hugo in Puerto Rico. Biotropica 23:317-323.

Snyder, N., J. Wiley, and C. Kepler. 1987. The parrots of Luquillo: Natural history and conservation of the Puerto Rican Parrot. Western Foundation of Vertebrate Zoology, Los Angeles, California, USA.

Teesdale, L. V., and J. W. Girard. 1945. Wood utilization in Puerto Rico. U.S. Department of Agriculture Forest Service Technical Paper Number 21.

Thomlinson, J. R., M. I. Serrano, T. del M. López, T. M. Aide, and J. K. Zimmerman. 1996. Land-use dynamics in a postagricultural Puerto Rican landscape (1936-1988). Biotropica 28:525-536.

USFS (U.S. Forest Service). 1985. Final land and resource management plan, Caribbean National Forest and Luquillo Experimental Forest. USDA Forest Service and Southern Forest Experiment Station, Rio Piedras, Puerto Rico.

Wadsworth, F. H. 1949. The development of the forest land resources of the Luquillo Mountains, Puerto Rico. Dissertation. University of Michigan, Ann Arbor, Michigan, USA. 1950. Notes on the climax forests of Puerto Rico and their destruction and conservation prior to 1900 . Caribbean Forester 11:38-47.

- 1952. Forest management in the Luquillo Mountains. II. Planning for multiple land use. Caribbean Forester 23:49-61.

1963. Annual Report of the Institute of Tropical Forestry. USDA Forest Service, Rio Piedras, Puerto Rico.

Wadsworth, F. H., and G. H. Englerth. 1959. Effects of the 1956 hurricane on forests in Puerto Rico. Caribbean Forester 20:38-52.

Waide, R. B., and A. E. Lugo. 1992. A research perspective on disturbance and recovery of a tropical montane forest. Page 173-190 in J. G. Goldammer, editor. Tropical forests in transition. Birkhäuser Verlag, Basil, Switzerland.

Walker, L. R., N. V. L. Brokaw, D. J. Lodge, and R. B. Waide, editors. 1991. Special issue: Ecosystem, plant, and animal responses to hurricane in the Caribbean. Biotropica 23: 313-521.

Walker, L. R., J. Voltzow, J. D. Ackerman, D. S. Fernandez, and N. Fetcher. 1992. Immediate impact of Hurricane Hugo on a Puerto Rican rain forest. Ecology 78:691-694.

Watkins, C., editor. 1993. Ecological effects of afforestation. Studies in the history and ecology of afforestation in Western Europe. C.A.B. International, Wallingford, UK.

Weaver, P. L. 1983. Tree growth and stand changes in the subtropical life zones of the Luquillo Mountains of Puerto Rico. U.S. Forest Service Research Paper SO-190. Southern Forest Experiment Station, New Orleans, Louisiana, USA.

1986. Hurricane damage and recovery in the mon- 
tane forests of the Luquillo Mountains of Puerto Rico. Caribbean Journal of Science 22:53-70.

. 1987. Structure and dynamics in the Colorado forest of the Luquillo Mountains of Puerto Rico. Dissertation. Michigan State University, East Lansing, Michigan, USA.

White, H. H. 1963. Variation in stand structure correlated with altitude in the Luquillo Mountains. Caribbean Forester 24:46-52.

Whitney, G. 1994. From coastal wilderness to fruited plain. A history of environmental change in temperate North America from 1500 to the present. Cambridge University Press, Cambridge, UK.

Williams, M. 1990. Transformations of the global environment: forests. Pages 179-202 in B. L. Turner, W. C. Clark,
R. W. Kates, J. F. Richards, J. T. Mathews, and W. B. Meyer, editors. The Earth as transformed by human action. Global and regional changes in the biosphere over the past 300 years. Cambridge University Press, Cambridge, UK.

Zimmerman, J. K., T. M. Aide, M. A. Rosario, M. I. Serrano, and L. J. Herrara. 1995. Effects of land management and a recent hurricane on forest structure and composition in the Luquillo Experimental Forest, Puerto Rico. Forest Ecology and Management 77:65-76.

Zimmerman, J. K., E. M. Everham III, R. B. Waide, D. J. Lodge, C. M. Taylor, and N. V. L. Brokaw. 1994. Responses of tree species to hurricane winds in subtropical wet forest in Puerto Rico: implications for tropical tree life histories. Journal of Ecology 82:911-922. 